\title{
Azemiopsin, a Selective Peptide Antagonist of Muscle Nicotinic Acetylcholine Receptor: Preclinical Evaluation as a Local Muscle Relaxant
}

\author{
Irina V. Shelukhina ${ }^{1}$, Maxim N. Zhmak ${ }^{1}$, Alexander V. Lobanov ${ }^{2}$, Igor A. Ivanov ${ }^{1}$, \\ Alexandra I. Garifulina ${ }^{1}$, Irina N. Kravchenko ${ }^{2}$, Ekaterina A. Rasskazova ${ }^{2}$, \\ Margarita A. Salmova ${ }^{2}$, Elena A. Tukhovskaya ${ }^{2}$, Vladimir A. Rykov ${ }^{2}$, Gulsara A. Slashcheva ${ }^{2}$, \\ Natalya S. Egorova ${ }^{1}$, Inessa S. Muzyka ${ }^{1}$, Victor I. Tsetlin ${ }^{1}$ and Yuri N. Utkin ${ }^{1, *}$ \\ 1 Shemyakin-Ovchinnikov Institute of Bioorganic Chemistry, Russian Academy of Sciences, \\ ul. Miklukho-Maklaya 16/10, Moscow 117997, Russia; shelukhina.iv@yandex.ru (I.V.S.); \\ mzhmak@gmail.com (M.N.Z.); chai.mail0@gmail.com (I.A.I.); garifulinaai@gmail.com (A.I.G.); \\ natalyegorov@yandex.ru (N.S.E.); mis_kou@mail.ru (I.S.M.); vits@mx.ibch.ru (V.I.T.) \\ 2 Branch of the Shemyakin-Ovchinnikov Institute of Bioorganic Chemistry, Russian Academy of Sciences, \\ Pushchino 142290, Moscow Region, Russia; lobanov-av@yandex.ru (A.V.L); ikravchenko@bibch.ru (I.N.K.); \\ katyarass@mail.ru (E.A.R.); mak401@gmail.com (M.A.S.); elentuk@mail.ru (E.A.T.); \\ vladimirrykov@email.su (V.A.R.); slashcheva_ga@mail.ru (G.A.S.) \\ * Correspondence: Yutkin@yandex.ru; Tel.: +7-495-336-6522
}

Received: 3 November 2017; Accepted: 2 January 2018; Published: 7 January 2018

\begin{abstract}
Azemiopsin (Az), a linear peptide from the Azemiops feae viper venom, contains no disulfide bonds, is a high-affinity and selective inhibitor of nicotinic acetylcholine receptor (nAChR) of muscle type and may be considered as potentially applicable nondepolarizing muscle relaxant. In this study, we investigated its preclinical profile in regard to in vitro and in vivo efficacy, acute and chronic toxicity, pharmacokinetics, allergenic capacity, immunotoxicity and mutagenic potency. The peptide effectively inhibited $\left(\mathrm{IC}_{50} \sim 19 \mathrm{nM}\right.$ ) calcium response of muscle nAChR evoked by $30 \mu \mathrm{M}$ $\left(\mathrm{EC}_{100}\right)$ acetylcholine but was less potent $\left(\mathrm{IC}_{50} \sim 3 \mu \mathrm{M}\right)$ at $\alpha 7 \mathrm{nAChR}$ activated by $10 \mu \mathrm{M}\left(\mathrm{EC}_{50}\right)$ acetylcholine and had a low affinity to $\alpha 4 \beta 2$ and $\alpha 3$-containing $n A C h R$, as well as to $\mathrm{GABA}_{\mathrm{A}}$ or $5 \mathrm{HT}_{3}$ receptors. Its muscle relaxant effect was demonstrated at intramuscular injection to mice at doses of 30-300 $\mu \mathrm{g} / \mathrm{kg}, 30 \mu \mathrm{g} / \mathrm{kg}$ being the initial effective dose and $90 \mu \mathrm{g} / \mathrm{kg}$ - the average effective dose. The maximal muscle relaxant effect of $\mathrm{Az}$ was achieved in 10 min after the administration and elimination half-life of Az in mice was calculated as 20-40 min. The longest period of Az action observed at a dose of $300 \mu \mathrm{g} / \mathrm{kg}$ was $55 \mathrm{~min}$. The highest acute toxicity (LD $50510 \mu \mathrm{g} / \mathrm{kg}$ ) was observed at intravenous injection of $\mathrm{Az}$, at intramuscular or intraperitoneal administration it was less toxic. The peptide showed practically no immunotoxic, allergenic or mutagenic capacity. Overall, the results demonstrate that $\mathrm{Az}$ has good drug-like properties for the application as local muscle relaxant and in its parameters, is not inferior to the relaxants currently used. However, some Az modification might be effective to extend its narrow therapeutic window, a typical characteristic and a weak point of all nondepolarizing myorelaxants.
\end{abstract}

Keywords: nicotinic acetylcholine receptor; azemiopsin; preclinical studies; toxicity; pharmacokinetics; myorelaxant

Key Contribution: Key Contribution: Investigation of the preclinical profile of azemiopsin demonstrated its high affinity and specificity for muscle type nicotinic acetylcholine receptor as well as good muscle relaxant capacity. Toxicology studies in mice indicated that azemiopsin was well tolerated during chronic dosing and showed no immunotoxicity, allergenic or mutagenic activity, which made it a good candidate for application as a local muscle relaxant. 


\section{Introduction}

A linear peptide azemiopsin $(\mathrm{Az})$ isolated from the Azemiops feae viper venom contains no disulfide bonds [1] and can be easily prepared by peptide synthesis. It is a high-affinity and selective inhibitor of muscle-type nicotinic acetylcholine receptor (nAChR) involved in fast synaptic signal transduction at nerve-muscle junction [2]. These receptors are well-known targets for muscle relaxant drugs (e.g., [3]). Muscle relaxants reduce the tone of the skeletal muscle with a decrease in motor activity up to complete immobilization. These drugs are generally classified into central muscle relaxants, which disrupt the transmission of excitation in the central nervous system and muscle relaxants of peripheral action that primarily and specifically disturb neuromuscular transmission.

Peripheral muscle relaxants can affect the signal transmission both at the presynaptic and postsynaptic membrane of the neuromuscular junction. The drugs acting at postsynaptic membrane are classified into depolarizing and nondepolarizing muscle relaxants (NMR). The action of depolarizing muscle relaxants (e.g., succinylcholine) is based on the persistent depolarization of the postsynaptic membrane, which makes impossible the propagation of the action potential and causes relaxation of the muscle fiber. NMRs (such as $d$-tubocurarine, atracurium, rocuronium) block the binding of acetylcholine to $\mathrm{AAChR}$ and disturb its function [4].

Nowadays, the muscle relaxants are used generally during large operations in order to achieve relaxation of the muscles (especially the abdomen) and thereby facilitate surgical manipulation. For most operations, the basic condition is a good relaxation of the striated muscles. NMRs are usually administered during anesthesia to facilitate endotracheal intubation and/or to improve surgical conditions. Currently, clinical practice cannot do without them. Muscle relaxants allowed reducing the depth of anesthesia and better controlling the conditions of the body's systems. In addition to anesthesiology, muscle relaxants have found application in traumatology and orthopedics for muscle relaxation in the treatments of dislocations, fractures, diseases of the back and ligament. Short-acting drugs in combination with general anesthetic agents are often used to facilitate laryngoscopy, bronchoscopy and esophagoscopy. NMRs are applied parenterally, almost always injected intravenously.

It should be noted that NMRs have undesirable side effects, primarily associated with their effects on the autonomic nervous system and with the release of histamine. The reason for these effects is the insufficient selectivity of low molecular NMR for muscle-type nAChR. Moreover, a number of side effects are due to blockade or activation of the muscarinic acetylcholine receptor $[5,6]$. Because of these side effects, $d$-tubocurarine is practically not applied today.

To treat conditions where muscles spasms and spasticity are a problem, muscle relaxants are also used. Muscle spasms are caused by an involuntary contraction of the muscles, which is often painful and causes difficulty in performing everyday tasks. Spasticity occurs when a muscle contracts and remains in this tight position, becoming very stiff and almost impossible to use. In cases like this, muscle relaxants are used to control stiffness and involuntary movements. They are used to treat so-called muscle dystonia. Dystonia is defined by Dystonia Medical Research Foundation as "a movement disorder characterized by sustained or intermittent muscle contractions causing abnormal, often repetitive, movements, postures, or both. Dystonic movements are typically patterned, twisting and may be tremulous. Dystonia is often initiated or worsened by voluntary action and associated with overflow muscle activation" [7]. Examples of muscle dystonias are blepharospasm (involuntary squinting), cervical dystonia (torticollis), spasticity (hypertonicity) of skeletal muscle, writer's cramp, foot dystonia, etc. The problem of constant high tone of particular groups of muscles also exists at spastic form of cerebral palsy. Currently, according to the European (http:/ / dystonia-europe.org) and American (http:/ / www.dystonia-foundation.org/) dystonia societies, the number of patients with various forms of dystonia is 500,000 in Europe and 300,000 in the United States. According to the Research Foundation for Cerebral Palsy Associations (UCPA: http:/ /www.ucp.org/), there are approximately 760,000 patients with this disease in the United States. In Russia, the number of patients with muscular dystonia is estimated at 80,000-140,000 people and cerebral palsy-150,000-200,000. 
Peripheral muscle relaxants have become medications for the treatment of muscle dystonia. Historically, the first applied in clinical practice peripheral relaxants were low-molecular alkaloids. After these first low-molecular cholinergic blockers, showing a number of side effects but being used up to the present time, the botulinum toxin has appeared. Currently, the main method of treatment for muscular dystonia and spastic form of cerebral palsy is the injection of botulinum toxin into the muscles involved in hyperkinesis. In 1989, the "BOTOX" (one of the drugs based on botulinum toxin) has been approved by the FDA for the treatment of blepharospasm, in 2000-cervical dystonia, in 2010 - spasticity at the elbow, wrist and fingers. The clinical effect is achieved in $85-90 \%$ of cases and lasts 2-3 months, however patients are in need of repeated administration of the drug: for spastic torticollis - 2 injections per year, blepharospasm-3-4, cerebral palsy-2 times a year. With the apparent effectiveness of "BOTOX", there are a number of disadvantages associated with side effects, which include itching, burning, swelling at the injection site, in some patients there is a general muscle weakness during the first two weeks after application of the preparation, antibody formation shows in $3-10 \%$ of patients. Even the duration of its effect is a disadvantage, since it does not allow promptly adjusting the dose of the drug in accordance with individual tolerability. A significant drawback of the drug is associated with the mechanism of action of botulinum toxin at the molecular level.

Negative moments of this mechanism of action (and especially its duration) are progressive atrophy of muscle fiber with a decrease in the average diameter of the fiber, scattering of nAChRs from the site of the synapse and a decrease in the activity of synaptic acetylcholinesterase. On rabbits, it was shown that after the injections of botulinum toxin that lasts for six months, the reduction in muscle mass could reach $76 \%$ and the contractile fibers could be replaced by fatty tissue elements. Currently, there are no medicines capable of replacing BOTOX in the treatment of muscular dystonia in the world. Therefore, the task of creating new effective drugs that do not have side effects, for local therapy of muscular dystonia is extremely urgent.

Muscle relaxants of peptide nature may be considered as alternatives to low-molecular alkaloids with a large number of side effects and to extremely toxic protein botulinum toxin. Peptides are not xenobiotics and, as a rule, have high selectivity to specific targets, which is due to the very nature of peptide-protein recognition. The natural source of such peptides has always been the animal venoms, especially the venoms of molluscs and snakes [8]. In the venoms of molluscs and snakes, polypeptide and peptide compounds acting on neuromuscular transmission have been identified and potentially can be regarded as agents for the treatment of muscular dystonia. In particular, the discovery and characterization of Az, blocking the neuromuscular transmission, open the possibility for the development of a novel muscle relaxant. As an inhibitor of muscle nAChR, Az may be regarded as a potentially applicable muscle relaxant itself [9]. This paper reports the results of preclinical studies, including single- and repeated-dose toxicities, immunotoxicity, pharmacokinetic and other studies. Overall, the results obtained demonstrate that Az has good drug-like properties.

\section{Results}

\subsection{Az Synthesis}

The Az peptide was prepared by a solid phase synthesis using a general Fmoc-strategy. The principal scheme was adopted from [10]. However, to minimize the consumption of materials for large-scale synthesis needs, all steps in the procedure were optimized and standardized. Thus, to determine the optimal excesses of amino acid derivatives, pilot experiments were performed. It was found, that for the first stage of the coupling of the C-terminal proline residue to a polymer, the 5-fold excess of the protected amino acid was necessary. For the coupling of the subsequent residues, the 4-fold excesses were enough. The couplings of the seventh and subsequent residues required the increase of reaction time from 1 to $2 \mathrm{~h}$. The modified scheme of synthesis allowed to avoid unnecessary reagent consumption, in particular, of expensive protected amino acids. Optimization experiments showed that the repeated condensations were necessary only for coupling of residues His9 and Pro15. 
The amounts of solvents and coupling reagents were optimized as well, reducing their consumption by several times. Large-scale purification of the peptide was performed in two steps. Ion exchange chromatography on a weak cation exchanger under moderately basic conditions was used at the first step. It allowed to obtain the peptide with purity of about $90 \%$ without any organic solvent consumption. To meet pharmacopeia specifications, the final purification step was carried out by a reversed-phase HPLC, increasing the substance purity to greater than $97 \%$ (Figure 1). Using the optimized procedure, the final product, Az, was obtained with $20 \%$ yield.

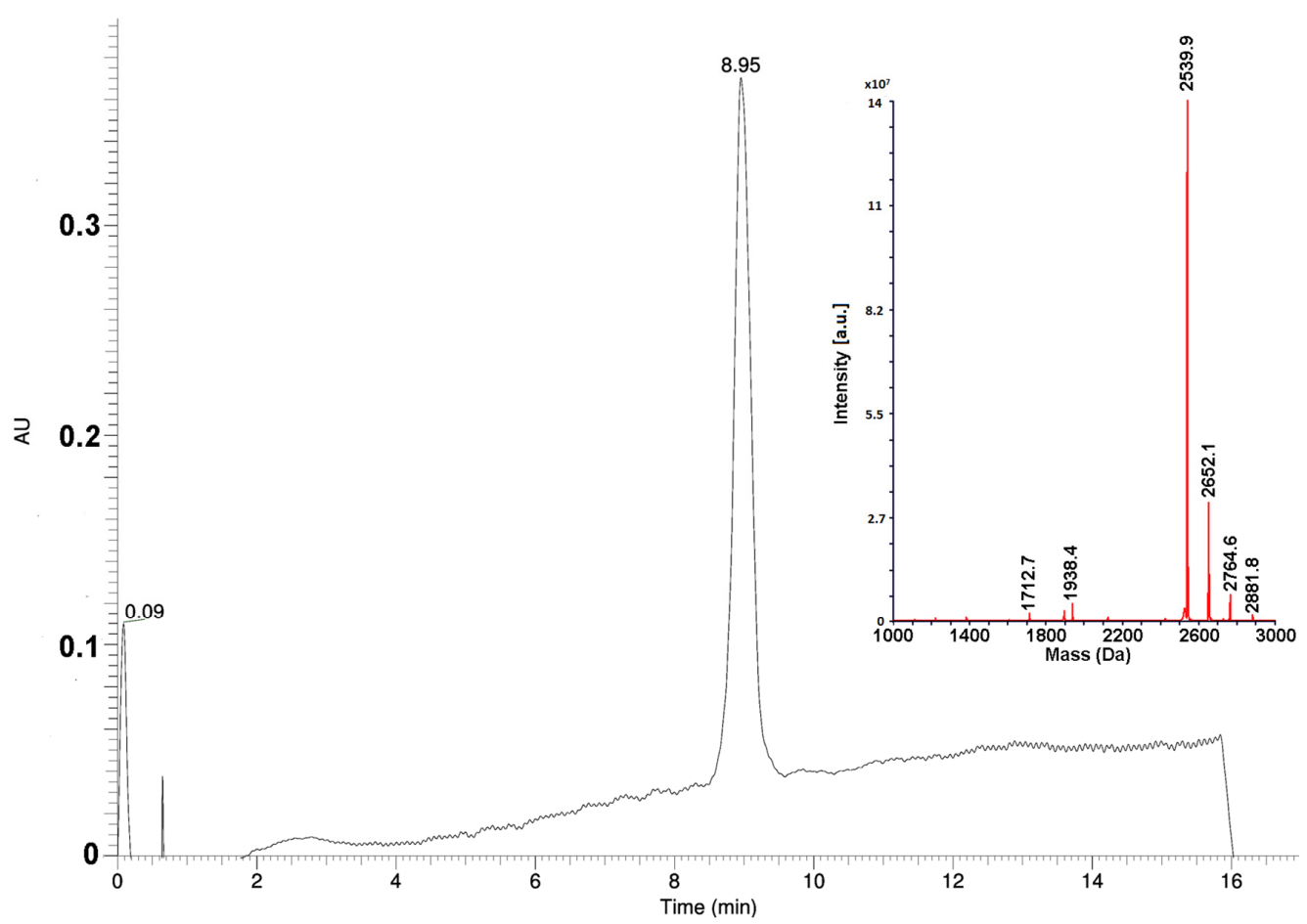

Figure 1. Analytical UPLC-MS on Phenomenex Aeris PEPTIDE XB-C18 column $(1.7 \mu \mathrm{m}, 2.1 \times 150 \mathrm{~mm})$ using a linear acetonitrile gradient from 10 to 35\%. Inset. Deconvoluted mass-spectrum of Az sample obtained after the final purification step. a.u., arbitrary unit.

\subsection{Efficacy and Specificity of Az In Vitro}

To study a specific activity and selectivity of Az in vitro, two different methods were used: electrophysiological method of two-electrode voltage-clamp on Xenopus oocytes and calcium imaging using the genetically encoded calcium sensor Case12 or the low-molecular weight calcium indicator Fluo-4. In calcium imaging experiments on mouse muscle type $\alpha 1 \beta 1 \varepsilon \delta \mathrm{nAChR}, \mathrm{Az}$ showed a high inhibitory activity in nanomolar range $\left(\mathrm{IC}_{50}=19 \pm 8 \mathrm{nM}\right.$, Figure 2a). Az also manifested ability to interact with the human neuronal homopentameric $\alpha 7 \mathrm{nAChR}$ but with a much lower affinity $\left(\mathrm{IC}_{50}=2.67 \pm 0.02 \mu \mathrm{M}\right.$, Figure $\left.2 \mathrm{~b}\right)$. It should be mentioned, that the corresponding cellular calcium responses were provoked by acetylcholine ( $\mathrm{ACh}$ ) at concentrations of $30 \mu \mathrm{M}$ (EC $\mathrm{E}_{100}$ on muscle $\left.\mathrm{nAChR}\right)$ and $10 \mu \mathrm{M}\left(\mathrm{EC}_{50}\right.$ on $\left.\alpha 7 \mathrm{nAChR}\right)$, respectively [11]. Electrophysiology experiments discovered no influence of $\mathrm{Az}$ on ion currents induced by $20 \mu \mathrm{M}$ nicotine in rat neuronal heteromeric $\alpha 4 \beta 2 \mathrm{nAChR}$ at a concentration up to $50 \mu \mathrm{M}$ (Figure $2 \mathrm{c}$ ). Besides, no Az activity against human neuronal heteromeric $\alpha 3$-containing nAChRs $(\alpha 3 \beta 2, \alpha 3 \beta 4$, etc.) expressed in neuroblastoma SH-SY5Y cells was detected by calcium imaging at a concentration up to $100 \mu \mathrm{M}$ (Figure $2 \mathrm{f}$ ). In control experiments using the same cellular system, calcium responses induced by $100 \mu \mathrm{M}$ nicotine $\left(\mathrm{EC}_{50}=22 \pm 2 \mu \mathrm{M}\right.$, Figure $\left.2 \mathrm{~d}\right)$ were successfully inhibited by $\alpha$-conotoxin $\mathrm{MII}\left(\mathrm{IC}_{50}=60 \pm 4 \mathrm{nM}\right.$, Figure 2e), a specific antagonist of $\alpha 3$-containing $n A C h R s$. In sum, these data demonstrated high selectivity of the Az action on muscle nAChR. 
For comparison, we have tested NMR rocuronium in some in vitro experiments and found that at muscle type receptor it was less effective than $\mathrm{Az}, \mathrm{IC}_{50} \mathrm{~s}$ being $257.06 \pm 95.54 \mathrm{nM}$ and $19 \pm 8 \mathrm{nM}$ for rocuronium and $\mathrm{Az}$, respectively (Figures $2 \mathrm{a}$ and $3 \mathrm{a}$ ). At the human neuronal homopentameric $\alpha 7$ $\mathrm{nAChR}$ rocuronium showed also lower affinity with $\mathrm{IC}_{50}$ of $25.69 \pm 4.5 \mu \mathrm{M}$ (Figure $3 \mathrm{~b}$ ) as compared to $2.67 \pm 0.02 \mu \mathrm{M}$ for $\mathrm{Az}$ (Figure $2 \mathrm{~b}$ ). In contrast to $\mathrm{Az}$, at concentration up to $100 \mu \mathrm{M}$ (Figure $2 \mathrm{f}$ ) manifesting no activity against human neuronal heteromeric $\alpha 3$-containing nAChRs $(\alpha 3 \beta 2, \alpha 3 \beta 4$, etc.) expressed in neuroblastoma SH-SY5Y cells, rocuronium dose-dependently inhibited these nAChR subtypes (Figure 3c). At $200 \mu \mathrm{M}$ rocuronium inhibited Nic induced currents by about 60\% (Figure 3c).
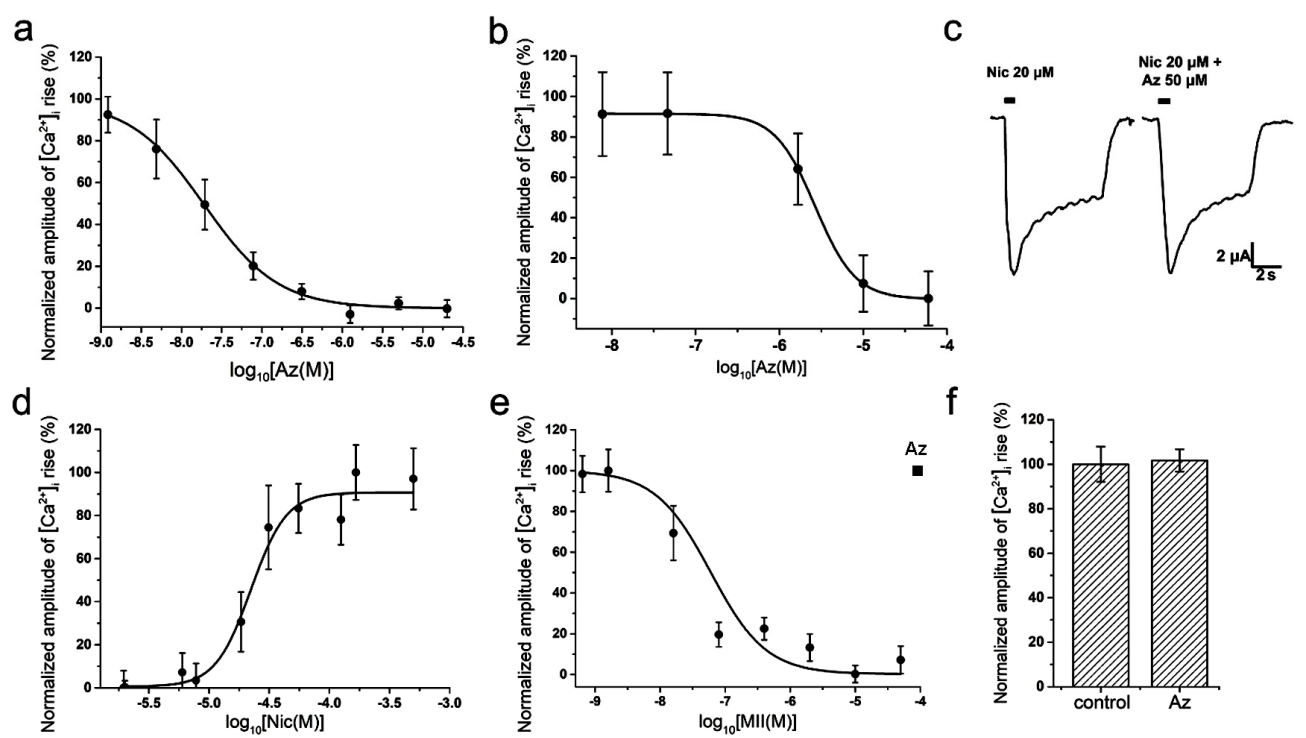

Figure 2. Interaction of $\mathrm{Az}$ with muscle and neuronal nAChRs. Inhibitory curves of $\mathrm{Az}$ action on ACh $(30$ and $10 \mu \mathrm{M})$-evoked intracellular calcium concentration $\left(\left[\mathrm{Ca}^{2+}\right]_{\mathrm{i}}\right)$ rises in neuroblastoma Neuro2a cells expressing (a) muscle $\alpha 1 \beta 1 \varepsilon \delta$ and (b) $\alpha 7 \mathrm{nAChRs,} \mathrm{respectively.} \mathrm{(c)} \mathrm{Representative}$ nicotine (Nic)-induced current traces through $\alpha 4 \beta 2 \mathrm{nAChR}$ and (d) dose-response curve of $\left[\mathrm{Ca}^{2+}\right]_{\mathrm{i}}$ amplitude rise in neuroblastoma SH-SY5Y cells expressing $\alpha 3$-containing $\mathrm{nAChRs}$ in response to different concentrations of Nic. There are no inhibitory effects of Az on Nic-evoked (c) ion currents and (f) calcium responses mediated by $\alpha 4 \beta 2$ and $\alpha 3$-containing nAChRs, respectively $(p>0.05$, Mann-Whitney U test). (e) Inhibitory curve of $\alpha$-conotoxin MII action on Nic $(100 \mu \mathrm{M})$-evoked $\left[\mathrm{Ca}^{2+}\right]_{\mathrm{i}}$ rise in SH-SY5Y cells expressing $\alpha 3$-containing nAChRs. Each point represents data obtained from 4 independent experiments (mean \pm SEM).
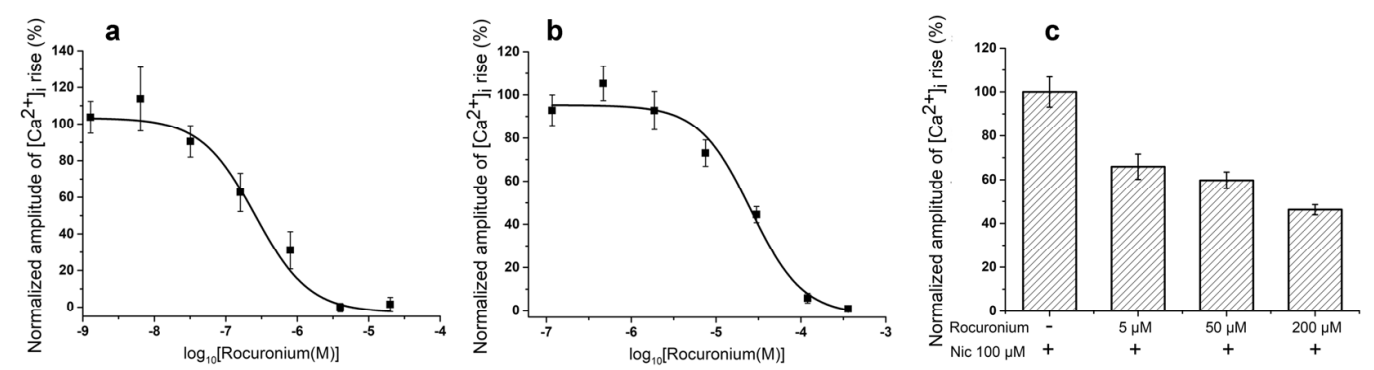

Figure 3. Interaction of rocuronium with muscle and neuronal nAChRs. Inhibitory curves of rocuronium action on $\mathrm{ACh}(30$ and $10 \mu \mathrm{M})$-evoked intracellular calcium concentration $\left(\left[\mathrm{Ca}^{2+}\right]_{\mathrm{i}}\right)$ rises in neuroblastoma Neuro2a cells expressing (a) muscle $\alpha 1 \beta 1 \varepsilon \delta$ and (b) $\alpha 7 \mathrm{nAChRs,} \mathrm{respectively.} \mathrm{Inhibition}$ of $\left[\mathrm{Ca}^{2+}\right]_{i}$ amplitude rise induced by Nic $(100 \mu \mathrm{M})$ in neuroblastoma SH-SY5Y cells expressing $\alpha 3$-containing $n A C h R s$ by different concentrations of rocuronium (c). Each point represents data obtained from 4 independent experiments (mean \pm SEM). 


\subsection{In Vivo Efficacy Tests}

\subsubsection{In Vivo Az Efficacy}

To study a specific activity of $\mathrm{Az}$ as an agent blocking neuromuscular transmission for the treatment of muscular dystonia, its effect on mouse muscular strength was estimated. Single administration of $\mathrm{Az}$ in the muscles of the forelimbs at doses of $0.03,0.1$ and $0.3 \mathrm{mg} / \mathrm{kg}$ caused a significant decrease in their muscular strength (Figure 4), while the dose of $0.01 \mathrm{mg} / \mathrm{kg}$ was not effective (Figure S1). The longest period of Az action was observed for a dose of $0.3 \mathrm{mg} / \mathrm{kg}$ and was maintained for $55 \mathrm{~min}$ from the 5 th to the 60th minute after its administration. The maximal muscle relaxant effect of $\mathrm{Az}$ for all the doses studied was achieved $10 \mathrm{~min}$ after its administration and was preserved until the 30th minute. The dose of $0.03 \mathrm{mg} / \mathrm{kg}$ was considered as an initial effective dose. The average effective dose at the maximum response point (10 min after injection) was $0.09 \mathrm{mg} / \mathrm{kg}$. These in vivo data showed the good muscle relaxing properties of Az.

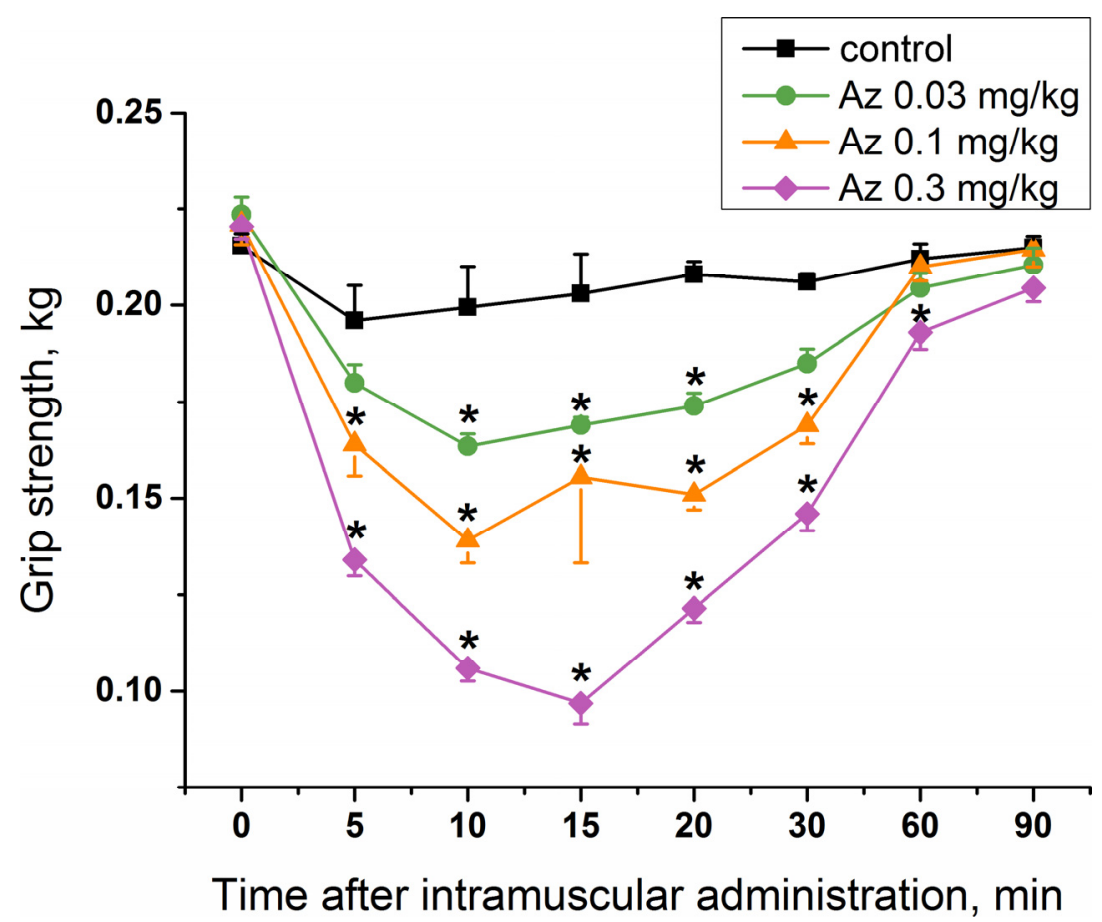

Figure 4. Muscle relaxant effect of Az. The time courses of a grip strength of mouse (ICR males) forelimbs at 0-90 $\mathrm{min}$ after $\mathrm{Az}(0.03,0.1$ and $0.3 \mathrm{mg} / \mathrm{kg}$ ) or normal saline (control) intramuscular administration. The results are presented as mean values $\pm \mathrm{SEM}, n=10$. Significant differences in the forelimb strength were revealed between control and experimental groups (one-way repeated measures ANOVA, $\left.{ }^{*} p<0.05\right)$.

\subsubsection{In Vivo Rocuronium Efficacy}

The rocuronium effect was studied at doses of $0.13 \mathrm{mg} / \mathrm{kg}, 0.1 \mathrm{mg} / \mathrm{kg}$ and $0.08 \mathrm{mg} / \mathrm{kg}$. The dose of $0.13 \mathrm{mg} / \mathrm{kg}$ was lethal and after $60 \mathrm{~s}$ the animal lost muscle tone (grip strength $=0 \mathrm{~kg}$ ) and the ability to move. The introduction of rocuronium at doses of 0.08 and $0.1 \mathrm{mg} / \mathrm{kg}$ did not cause the death of animals and showed a dose-dependent decrease in muscle tone within the first 5 min after administration. A statistically significant effect compared to the control was observed 2 min after administration of rocuronium at a dose of $0.1 \mathrm{mg} / \mathrm{kg}$ (Figure 5). At the 3rd minute after the administration, muscle strength began to recover and did not significantly differ from the control. At a dose of $0.08 \mathrm{mg} / \mathrm{kg}$ no statistically significant difference from control was found and only a tendency 
to decrease the muscular strength was observed with the greatest effect at the 2nd and 3rd minutes (Figure 5).

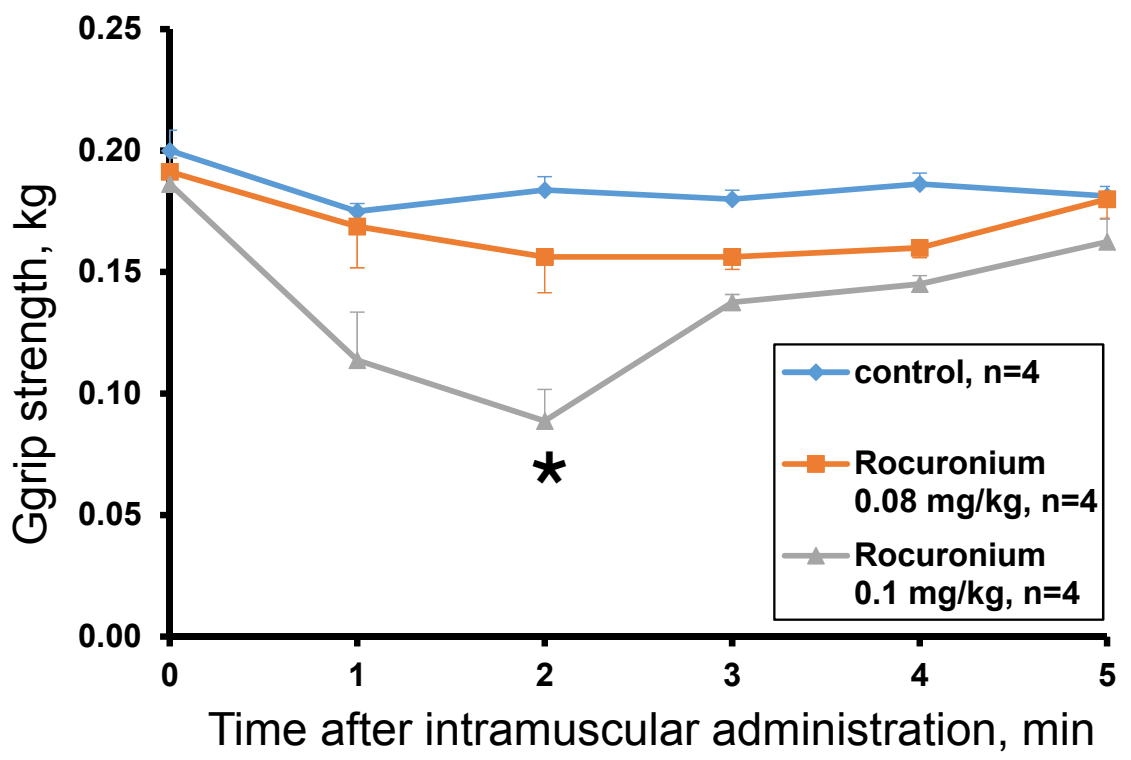

Figure 5. Muscle relaxant effect of rocuronium. The time courses of a grip strength of mouse (ICR males) forelimbs at $0-5 \mathrm{~min}$ after rocuronium $(0.08,0.1 \mathrm{mg} / \mathrm{kg}$ ) or normal saline (control) intramuscular administration. The results are presented as mean values $\pm \mathrm{SEM}, n=4$. Significant differences in the forelimb strength were revealed between control and experimental groups (one-way repeated measures ANOVA, $\left.{ }^{*} p<0.05\right)$.

\subsection{Pharmacokinetics of $A z$}

To study a pharmacokinetics of Az, its radioiodinated ${ }^{125} \mathrm{I}$-labeled analog $\left(\left[{ }^{125} \mathrm{I}\right]-\mathrm{Az}\right)$ was prepared.

\subsubsection{Preparation of $\left[{ }^{125} \mathrm{I}\right]-\mathrm{Az}$}

In position 9, Az molecule contains a histidine residue which may be subjected to electrophilic iodination as published earlier [12]. However, two tryptophan residues (Trp3 and Trp4) might be oxidized under iodination conditions complicating the isolation of the target iodinated product. To overcome this problem, both tryptophan residues were protected by formylation. Diformyl-Az was iodinated following a standard chloramine protocol, optimized to obtain a better yield of iodinated peptide [13]. For the iodination reaction, a preliminary screening of the reaction conditions at which the $\mathrm{pH}$ and the substrate/chloramine ratio varied was carried out. It was not possible to obtain radioiodinated $\mathrm{Az}$ derivative containing only one iodine atom, therefore di-iodinated analogue was prepared. The complete iodination was achieved at $\mathrm{pH} 6.8$ with 3 equivalents of iodide and 2.2 equivalents of chloramine $\mathrm{T}$ relative to peptide. The di-iodinated product was purified by HPLC and deprotected under alkaline conditions, followed by alkali neutralization. Analytical HPLC showed full removal of protecting groups, so the product was used further without additional purification.

\subsubsection{Pharmacokinetics Studies}

Single intravenous (iv) and intramuscular (im) administrations of $\left[{ }^{125} \mathrm{I}\right]-\mathrm{Az}$ at doses of 0.25 and $0.50 \mathrm{mg} / \mathrm{kg}$ to male ICR mice were performed. No lethality was observed after $\left[{ }^{125} \mathrm{I}\right]-\mathrm{Az}$ injections at these doses. The main pharmacokinetic parameters such as the area under a pharmacokinetic curve $(\operatorname{AUC}(0 \rightarrow \mathrm{t}))$, the maximum Az concentration in mouse blood $\left(\mathrm{C}_{\max }\right)$ and its excretion half-life $\mathrm{T}_{1 / 2}$ were determined (Table 1 ), allowing to evaluate the processes of excretion and elimination of the peptide. 
Table 1. The main pharmacokinetic parameters estimated after a single intramuscular (im) or intravenous (iv) administration of Az to male ICR mice: the area under a pharmacokinetic curve $(\operatorname{AUC}(0 \rightarrow t))$, the maximum Az concentration in mouse blood $\left(C_{\max }\right)$ and its excretion half-life $T_{1 / 2}$.

\begin{tabular}{cccc}
\hline Route/Dose & $\begin{array}{c}\text { AUC }(\mathbf{0} \rightarrow \mathbf{t}), \\
\mathbf{h} \times \mathbf{n g} / \mathbf{m L}\end{array}$ & $\begin{array}{c}\mathbf{C}_{\mathbf{m a x},} \\
\mathbf{n g} / \mathbf{m L}\end{array}$ & $\mathbf{T}_{\mathbf{1 / 2}}, \mathbf{h}$ \\
\hline $\mathrm{im} / 0.25 \mathrm{mg} / \mathrm{kg}$ & 328 & 278 & 0.30 \\
$\mathrm{im} / 0.50 \mathrm{mg} / \mathrm{kg}$ & 622 & 257 & 0.68 \\
$\mathrm{iv} / 0.25 \mathrm{mg} / \mathrm{kg}$ & 214 & 517 & 0.26 \\
$\mathrm{iv} / 0.50 \mathrm{mg} / \mathrm{kg}$ & 542 & 745 & 0.29 \\
\hline
\end{tabular}

For a single intravenous injection, the maximum concentration $\left(\mathrm{C}_{\max }\right)$ of $\left[{ }^{125} \mathrm{I}\right]-\mathrm{Az}$ in mouse blood was observed $1 \mathrm{~min}$ after injection and its excretion half-life $\left(\mathrm{T}_{1 / 2}\right)$ was estimated as 15-20 min (Figure 6a). With intramuscular administration, the maximum $\left[{ }^{125} \mathrm{I}\right]-\mathrm{Az}$ concentration $\left(\mathrm{C}_{\max }\right)$ was achieved within five minutes and the parameter $\mathrm{T}_{1 / 2}$ was calculated as $20-40 \mathrm{~min}$ (Figure $6 \mathrm{~b}$ ). In both modes of administration, the drug was almost completely removed from the free blood flow during $24 \mathrm{~h}$ (Figure $6 \mathrm{a}, \mathrm{b})$. A greater maximum drug concentration $\left(\mathrm{C}_{\max }\right)$ was observed at an intravenous route of administration than at intramuscular injection.

a

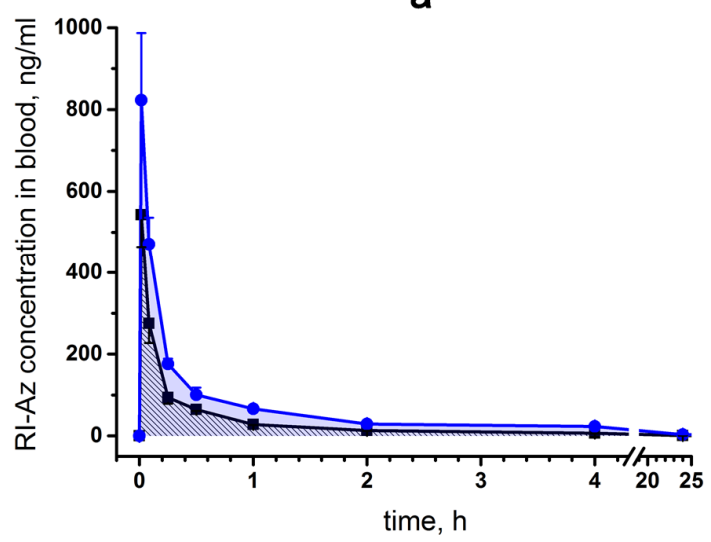

b

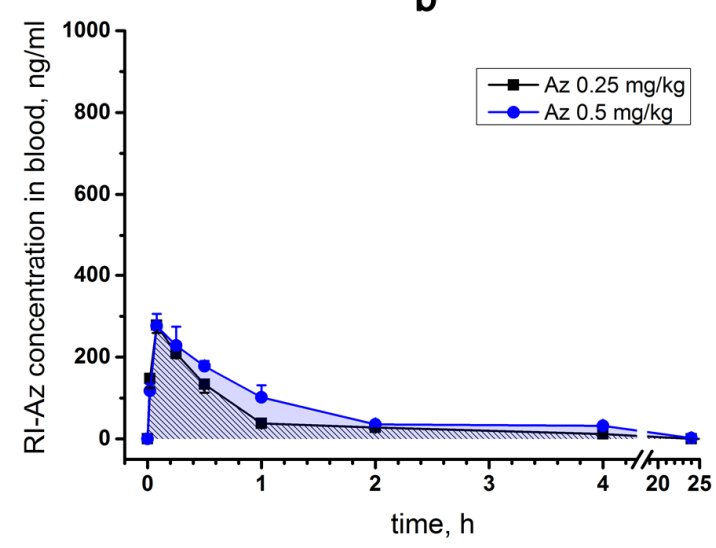

Figure 6. Pharmacokinetic curves of $\left[{ }^{125} \mathrm{I}\right]$-Az concentration in blood of male ICR mice 0-24 h after its (a) intravenous and (b) intramuscular administration at doses of 0.25 and $0.5 \mathrm{mg} / \mathrm{kg}$. The results are presented as mean values $\pm \mathrm{SD}, n=5$ (each plot point represents mean results for five animals).

\subsection{Acute Toxicity Tests}

\subsubsection{Acute Toxicity of Az}

The acute toxicity of Az after intraperitoneal administration to mice was determined earlier [1], the $\mathrm{LD}_{50}$ value was $2.57 \pm 0.27 \mathrm{mg} / \mathrm{kg}$. In the present work, we studied Az acute toxicity to male ICR mice after intravenous and intramuscular administration. The $\mathrm{LD}_{50}$ value was estimated as $0.51 \pm 0.06 \mathrm{mg} / \mathrm{kg}$ after Az intravenous administration.

A single intramuscular $\mathrm{Az}$ injection at doses of $0.8,0.775,0.75$ and $0.725 \mathrm{mg} / \mathrm{kg}$ resulted in a dose-dependent death of the mice. Death in $100 \%$ of cases was detected at a dose of $0.8 \mathrm{mg} / \mathrm{kg}$. The doses of 0.775 and $0.75 \mathrm{mg} / \mathrm{kg}$ resulted in the death of 4 animals out of 5 . At a dose of $0.725 \mathrm{mg} / \mathrm{kg}$, 3 animals died out of 5 and at $0.7 \mathrm{mg} / \mathrm{kg}$ all mice were alive. The death of animals at doses of 0.725 , $0.75,0.775,0.8 \mathrm{mg} / \mathrm{kg}$ was observed $19.7 \pm 5.9,28.8 \pm 16.0,15.8 \pm 4.3$ and $12.2 \pm 1.8 \mathrm{~min}$ after $\mathrm{Az}$ administration, respectively. Based on these data, LD50 of $0.732 \pm 0.13 \mathrm{mg} / \mathrm{kg}$ was calculated for $\mathrm{Az}$ at intramuscular injection. The maximal tolerant dose was $0.7 \mathrm{mg} / \mathrm{kg}$ after its intramuscular injection. No toxicity signs were observed at a dose of $0.3 \mathrm{mg} / \mathrm{kg}$ and lower used for grip strength tests. 
Intramuscular injection of Az was accompanied by external signs of intoxication, the severity of which was dose-dependent. Visible toxic signs appeared 5-7 min after administration and were characterized by impaired coordination of movements and loss of muscle tone, decreased motor activity, impaired breathing, decreased response to external stimuli. Maximal manifestations of intoxication were noted between 10 and $20 \mathrm{~min}$ after administration and were characterized by loss of motor activity, a lacunar posture or posture on the side, loss of muscle tone, loss of response to external stimulation, delayed or intermittent breathing, coma. Mice almost completely recovered within $60 \mathrm{~min}$ after injection. After this period, the animals showed a decrease in motor activity and muscle tone. Complete recovery from the toxic effect of large doses occurred $24 \mathrm{~h}$ after administration. No function disturbances caused by Az large doses were observed 14 days after the administration.

At intramuscular administration way, a maximal tolerated dose (MTD) was determined. MTD is the highest dose of a drug that does not cause unacceptable side effects. In mice, MTD for Az was determined as $0.7 \mathrm{mg} / \mathrm{kg}$; no lethality was observed at this dose. The doses up to $0.5 \mathrm{mg} / \mathrm{mL}$ used for the in vivo tests were lower than MTD of $0.7 \mathrm{mg} / \mathrm{kg}$ and induced no lethality as well.

\subsubsection{Acute Toxicity of Rocuronium}

Injection of rocuronium at a dose of $0.13 \mathrm{mg} / \mathrm{kg}$ caused the death of the test animal. The first signs of intoxication were detected $30 \mathrm{~s}$ after injection. The impaired coordination of movements, decreased muscle tone, decreased motor activity, increased respiratory movements, convulsions were observed. The severity of toxic disorders rapidly increased. After $60 \mathrm{~s}$, the animal lost muscle tone (grip strength $=0 \mathrm{~kg}$ ) and the ability to move, the frequency of respiratory movements decreased, the animal fell into a coma and then died $11.5 \mathrm{~min}$ after injection. Rocuronium at doses of 0.08 and $0.1 \mathrm{mg} / \mathrm{kg}$ did not cause the death of animals. A dose of $0.08 \mathrm{mg} / \mathrm{kg}$ did not induce visible signs of toxicity, while $0.1 \mathrm{mg} / \mathrm{kg}$ caused discoordination of movements, decreased muscle tone, gait disturbance, decrease or short-term loss of motor activity, increased respiratory movements, vocalization (in one animal). These toxicity signs disappeared in 3-4 min after drug administration.

\subsection{Subchronic Toxicity of $A z$}

For the study of the subchronic toxicity, the number of animals was increased in comparison with acute toxicity tests, because many biochemical, histological and other parameters needed to be measured. In order to reveal a statistically significant difference in these parameters, large groups of animals were used. For the studies, larger animals (rats) were used for experimenting with long-term administration of the drug and studying many blood parameters, this might be difficult for small animals such as mice.

On the basis of acute toxicity results a repeated dose 14-day intramuscular toxicity study was performed. During the 14-day period of $\mathrm{Az}$ administration at doses of 0.1 and $0.5 \mathrm{mg} / \mathrm{kg}$, it did not cause any evident signs of toxicity in male or female Sprague Dawley rats. The increase in the mean body weight of animals and in the food intake did not differ significantly between the experimental and control groups.

A 14-day Az treatment at a dose of $0.1 \mathrm{mg} / \mathrm{kg}$ did not lead to any changes in the hemogram of experimental animals relative to control ones. However, in male rats at a dose of $0.5 \mathrm{mg} / \mathrm{kg} \mathrm{Az}$ caused a statistically significant increase $(n=6, p<0.05$, Kruskall-Wallis ANOVA on ranks) in the number of platelets $(810 \pm 39 \mathrm{~g} / \mathrm{L})$ relative to the control level $(729 \pm 22 \mathrm{~g} / \mathrm{L})$. Two weeks after the $0.5 \mathrm{mg} / \mathrm{kg} \mathrm{Az}$ administration the level of platelets was still slightly increased but non-significantly. There were no differences in the hemograms of female rats receiving Az at both doses and the control group.

A few biochemical parameters of rat blood serum were changed at the end of 28-day subchronic toxicity experiment (14 days of $\mathrm{Az}$ administration and 14 days of its withdrawal) in comparison to the control animal group. In the blood serum of males receiving $\mathrm{Az}$ at a dose of $0.5 \mathrm{mg} / \mathrm{kg}$, a significant decrease in the mean level of triglycerides $(0.97 \mathrm{mmol} / \mathrm{L}$ vs. $1.25 \mathrm{mmol} / \mathrm{L}$ in control, $n=6, p<0.05$, Kruskall-Wallis ANOVA on ranks) was observed. In a group of female rats treated with 
$0.1 \mathrm{mg} / \mathrm{kg}$ of $\mathrm{Az}$, the levels of cholesterol $(2.82 \pm 0.36 \mathrm{mmol} / \mathrm{L}$ vs. $3.55 \pm 0.39 \mathrm{mmol} / \mathrm{L}$ in control $)$ and calcium $(3.09 \pm 0.06$ vs. $3.25 \pm 0.09 \mathrm{mmol} / \mathrm{L}$ in control) were reduced significantly $(n=6, p<0.05$, Kruskall-Wallis ANOVA on ranks).

In two weeks after the Az administration the rats were euthanized. Post-mortem necropsy of animals did not reveal any abnormalities in the anatomy or in the absolute weight of their internal organs. However, some differences in a relative heart weight of male rats were observed. Thus, the mean relative heart weight in a rat group treated with $\mathrm{Az}$ at a dose of $0.5 \mathrm{mg} / \mathrm{kg}$ was significantly $(n=6$, $p<0.05$, Kruskall-Wallis ANOVA on ranks) reduced $(0.352 \pm 0.033 \%)$ in comparison with the control group of animals $(0.428 \pm 0.086 \%)$. Histological analysis was performed for the following organs and tissues: liver, stomach, kidneys, adrenal glands, lungs, heart, spleen, thymus, submandibular lymph nodes, ovaries, testes, brain, femoral muscle of the right and left paws (the injection site). No pathological changes were observed in the organs examined.

All observed changes in biochemical, hematological and other tested parameters were among physiologically normal variations for Sprague Dawley rats and did not indicate Az toxicity [14]. Thus, during 14-day intramuscular administration of $\mathrm{Az}$ in two doses of 0.1 and $0.5 \mathrm{mg} / \mathrm{kg}$, which are similar to the expected therapeutic doses, to female and male rats with a two-week withdrawal period the peptide showed no significant toxicity.

\subsection{Immunotoxicity of $A z$}

To study the possible immunotoxicity of $\mathrm{Az}$, its effects on

(1) cellular immunity (the delayed-type hypersensitivity reaction),

(2) immune response to a standard antigen and

(3) phagocytic activity of peritoneal macrophages was evaluated.

All three tests were carried out after 7-day intramuscular Az administration at doses of 0.15 and $0.5 \mathrm{mg} / \mathrm{kg}$ to male ICR mice. Control animals were treated with the sodium chloride physiological solution (normal saline).

To probe the $\mathrm{Az}$ influence on cellular immunity, the mice were primarily immunized subcutaneously (sbc) at the base of a tail with trinitrobenzenesulfonic acid $(10 \mathrm{mM}, 200 \mu \mathrm{L})$ and secondarily after 6 days with the same agent $(50 \mu \mathrm{L})$ in the left hind paw. Simultaneously, the physiological solution $(50 \mu \mathrm{L})$ was injected into the right control hind paw. Next day after the second immunization, the weight of left and right hind paws were compared and edema of the experimental paws was revealed in all animal groups (Figure 7a). However, Az treatment did not cause any significant changes in the degree of the observed edema, showing no influence on cellular immunity in mice (Figure 7a).

In the next test, the effect of a 7-day Az administration on mouse immune response to a bovine serum albumin (BSA) was determined. The mice from one control and two experimental groups were routinely immunized with BSA in two steps (1st and 10th days) and after a week the corresponding IgG titers were evaluated in mouse blood serum (Figure $7 \mathrm{~b}$ ). The obtained results did not demonstrate any significant difference in the immune response of mice treated with $\mathrm{Az}(0.15$ and $0.5 \mathrm{mg} / \mathrm{kg}) \mathrm{or}$ with the physiological solution (Figure $7 \mathrm{~b}$ ).

$\mathrm{Az}$ at doses of 0.15 and $0.5 \mathrm{mg} / \mathrm{kg}$ also did not significantly change the phagocytic activity (engulfing ink particles) of peritoneal macrophages, which were isolated from experimental animals, vs. control ones (Figure 7c). Thus, in all three tests no significant changes in the studied parameters of the immune system in animals receiving Az during a week were observed. 
a

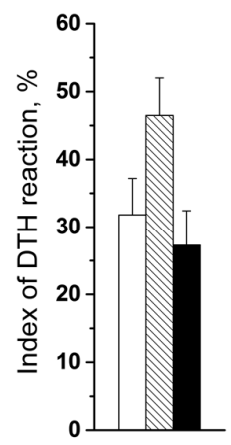

b

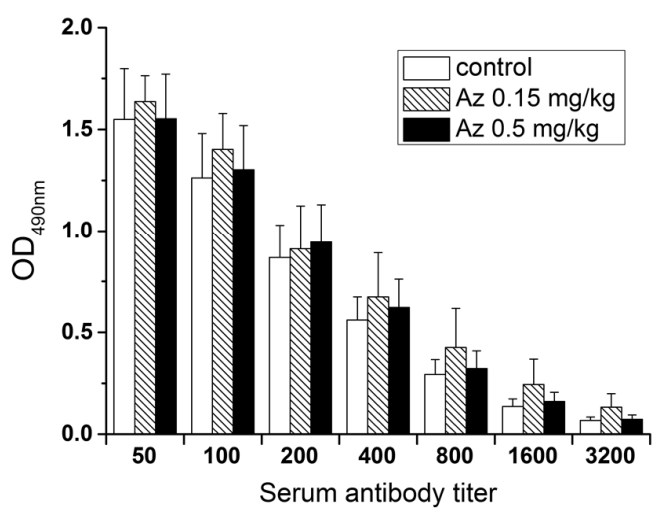

C

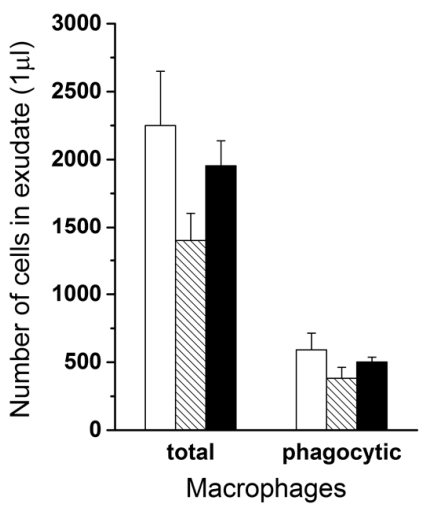

Figure 7. The influence of Az on immune system. The effect of 7-day intramuscular Az (0.15 and $0.5 \mathrm{mg} / \mathrm{kg}$ ) administration to male ICR mice (a) on their delayed-type hypersensitivity (DTH) to a specific antigen (10 $\mathrm{mM}$ trinitrobenzenesulfonic acid) manifested by paw edema, (b) on their immune response to a bovine serum albumin (BSA) and (c) on phagocytic activity of their peritoneal macrophages. (a) The presented indexes of DTH reactions reflect the normalized difference in the weights of treated and control mouse hind paws. (b) The titers of IgG in blood serum of mice from experimental and control groups after their standard immunization with BSA are presented. (c) The number of total and phagocytic (engulfing ink particles) macrophages in $1 \mu \mathrm{L}$ of peritoneal exudate isolated from experimental and control animals. In all three tests, there was no significant difference between control and experimental animals ( $p>0.05$, Kruskall-Wallis ANOVA on ranks) in the parameters studied. The results are presented as mean values \pm SEM, $n=5-10$.

\subsection{Allergenicity of $A z$}

To test the allergenicity of $\mathrm{Az}$, its ability to induce a delayed-type hypersensitivity reaction in male and female ICR mice at a dose of $0.15 \mathrm{mg} / \mathrm{kg}$ was investigated. The scheme of animal immunization (the 1st day subcutaneously and the 5th day in a left hind paw) was similar to the test with trinitrobenzenesulfonic acid but $\mathrm{Az}$ was used as an immunogen. In the control groups, the animals were first given the sodium chloride physiological solution (normal saline) subcutaneously and after 5 days were similarly injected with Az in a left hind paw. The degree of left hind paw edema was estimated 6,12 and $24 \mathrm{~h}$ after the second $\mathrm{Az}$ injection relatively to the control paw size (Figure 8). In all groups of animals, a small swelling of the experimental paws was observed $6 \mathrm{~h}$ after the second $\mathrm{Az}$ injection. After $12 \mathrm{~h}$ the revealed edema decreased and after $24 \mathrm{~h}$ there was practically no swelling. The size of the edema and its dynamics were not significantly different between the animal groups with preliminary Az sensitization and without it. In all tests carried out, no allergic reaction was detected. Thus, Az at a dose of $0.15 \mathrm{mg} / \mathrm{kg}$ demonstrated no allergic effect in the delayed-type hypersensitivity reaction test in ICR mice.

\subsection{Mutagenicity of $A z$}

To study Az mutagenicity in vitro, its ability to induce mutations in the hypoxanthine guanine phosphoribosyltransferase (hprt) gene of mammalian CHO-k1 cells was tested. This is the common assay for detection of gene mutations in mammalian cells [15]. For this purpose, Az was added to the cell growth medium at concentrations ranging from 2.8 to $2000 \mu \mathrm{g} / \mathrm{mL}$ for four hours in the presence or absence of a metabolic activation system (S9 mixture [16]) and after a cultivation period of 8 days, the cells were sub-cultured in the presence of a specific cytostatic agent 6-thioguanine. The inactivation of hprt gene due to any induced mutations led to the resistance of CHO-k1 cells to the cytostatic effect of this purine analog and allowed the selection and counting of the mutant cell colonies grown in its presence. 


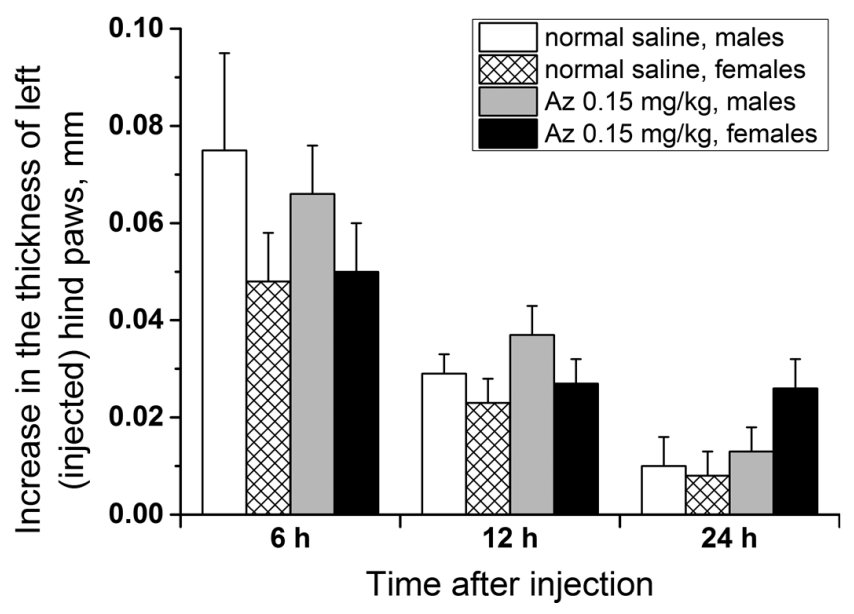

Figure 8. The capacity of $\mathrm{Az}(0.15 \mathrm{mg} / \mathrm{kg}$ subcutaneously) to provoke allergic (a delayed-type hypersensitivity) reaction in male and female ICR mice. The differences in the thickness of the experimental left (injected with $\mathrm{Az}$ ) and the control right hind paws are presented for animal groups with preliminary Az sensitization and without it 6,12 and $24 \mathrm{~h}$ after the second peptide administration. There was no significant difference in the increase in the thickness of left hind paws between all animal groups ( $p>0.05$, Kruskall-Wallis ANOVA on ranks). The results are presented as mean values \pm SEM, $n=10$.

As positive controls, two high-mutagenic agents were used: ethylnitrosurea (6.25 and 12.5 $\mu \mathrm{g} / \mathrm{mL}$ ) and methylcholanthrene $(2.5$ and $5 \mu \mathrm{g} / \mathrm{mL})$ in the absence and in the presence of the metabolic activation system, respectively. To determine the basic level of spontaneous mutations in the hprt gene, $\mathrm{CHO}-\mathrm{k} 1$ cells were cultivated in the intact growth medium before their sub-culturing in the presence of 6-thioguanine. The mean frequency of spontaneous mutations was evaluated as $25.2 \pm 1.6 \times 10^{-6}$. Although for all positive control conditions the statistically significant rise ( $n=6, p<0.05$, Kruskall-Wallis ANOVA on ranks) in the frequency of mutations in the hprt gene was observed (33.9-39.5 $\times 10^{-6}$ for ethylnitrosurea and 35.7-45.7 $\times 10^{-6}$ for methylcholanthrene), Az in all tested concentrations (up to $2000 \mu \mathrm{g} / \mathrm{mL}$ ) did not provoke any significant increase over a basic level of spontaneous mutations in this gene (23.5-30.2 $\left.\times 10^{-6}, p>0.05\right)$. Thus, in this cell system Az did not demonstrate any mutagenic capacity.

\section{Discussion}

As discussed above peptide and protein drugs in many cases possess higher efficacy and better specificity as compared to low molecular weight compounds. The Az, manifesting specific inhibiting activity against muscle $\mathrm{nAChR}$, is a good candidate to be a local muscle relaxant. However, to claim $\mathrm{Az}$ as a perspective medicine, it is necessary to check a number of its biological characteristics, including muscle relaxing efficacy, acute and chronic toxicity, pharmacokinetics, mutagenicity, immunotoxicity and allergenicity. The current study was undertaken to determine if Az has a perspective to be used as a local muscle relaxant and it was carried out according to General requirements to conduct preclinical studies of drugs as stated in Appendix No. 7 to the Rules of Good Laboratory Practice of the Eurasian Economic Union in the field of drug circulation [17].

Basing on these requirements, we have studied the pharmacology and in vivo efficacy of the Az, its pharmacokinetics and toxicology, including toxicity after its single and repeated administration, specific toxicity and mutagenicity. Earlier in competition experiments with radioactive $\alpha$-bungarotoxin, $\mathrm{Az}$ showed high affinity to muscle-type Torpedo nicotinic acetylcholine receptor (nAChR) ( $\mathrm{IC}_{50}$ $0.18 \pm 0.03 \mu \mathrm{M})$ and lower efficiency to human $\alpha 7 \mathrm{nAChR}\left(\mathrm{IC}_{50} 22 \pm 2 \mu \mathrm{M}\right)$ [1]. In Xenopus oocytes heterologously expressing human muscle-type $\mathrm{nAChR}$ it was more potent against the adult form $\left(\alpha 1 \beta 1 \varepsilon \delta, \mathrm{IC}_{50} 0.44 \pm 0.1 \mu \mathrm{M}\right)$ than the fetal form $\left(\alpha 1 \beta 1 \gamma \delta, \mathrm{IC}_{50} 1.56 \pm 0.37 \mu \mathrm{M}\right)$. In the present study, 
we have found that $\mathrm{Az}$ exhibited high affinity for mouse muscle $\alpha 1 \beta 1 \varepsilon \delta \mathrm{nAChR}$ (IC $5019 \pm 8 \mathrm{nM}$ ) but was less potent to human $\alpha 7 \mathrm{nAChR}\left(\mathrm{IC}_{50} 2.67 \pm 0.02 \mu \mathrm{M}\right)$ in calcium imaging assay. It was more active than rocuronium against both muscle and $\alpha 7 \mathrm{nAChR}$ and manifested higher selectivity to muscle receptor (about 140 times) as compared to rocuronium (about 100 more active to muscle type). In general, these data are in agreement with earlier results. At concentrations up to $100 \mu \mathrm{M}$, $\mathrm{Az}$ had no effect on heteromeric rat $\alpha 4 \beta 2$ or human $\alpha 3$-containing $\mathrm{nAChRs}(\alpha 3 \beta 2, \alpha 3 \beta 4$, etc.). It also showed no activity against $5-\mathrm{HT}_{3}$ receptors at concentration up to $10 \mu \mathrm{M}$ and $\mathrm{GABA}_{\mathrm{A}}(\alpha 1 \beta 3 \gamma 2$ or $\alpha 2 \beta 3 \gamma 2)$ receptors at concentration up to $100 \mu \mathrm{M}$ [1]. All these data show high Az selectivity to muscle type $\mathrm{nAChR}$. It should be noted that the nondepolarizing neuromuscular blocking agents now used as muscle relaxants reversibly and concentration-dependently inhibited in the low micromolar range the neuronal nAChRs, including $\alpha 3 \beta 2, \alpha 3 \beta 4, \alpha 4 \beta 2$ and $\alpha 7$ subtypes [18]. In our experiments, rocuronium dose-dependently inhibited neuronal $\alpha 3$-containing nAChRs. The mechanism (i.e., competitive vs. noncompetitive) of the block at the neuronal nAChRs was dependent both on the receptor subtype and the agent tested. Our data indicate that Az is more selective to muscle type nAChR than currently used relaxant, therefore it may produce less side effects in practice.

To determine the muscle relaxing capacity of $\mathrm{Az}$, its influence on the forelimb grip strength of male ICR mice was studied. Grip strength test is a widely used non-invasive method to quantify objectively the muscular strength of mice and rats and to investigate the effects of neuromuscular disorders and drugs. It is based on the natural tendency of a rodent to grasp a bar or grid when it is suspended by the tail $[19,20]$. It was found that a single Az injection in mouse forelimb muscles resulted in the decrease of its grip strength. The effect was dose-dependent and the strongest decrease was observed at the highest dose used $(0.3 \mathrm{mg} / \mathrm{kg})$. The effect was evident $5 \mathrm{~min}$ after administration and maintained for 25-55 min depending on the dose. For comparison, we have tested nondepolarizing muscle relaxant rocuronium and found that it was very poor in grip strength test. Its effect was extremely fast and disappeared with 5 min after injection. Moreover, at a dose of $0.13 \mathrm{mg} / \mathrm{kg}$ it was lethal to mice and at $0.08 \mathrm{mg} / \mathrm{kg}$ produced no statistically significant relaxing effect as compared to control. Thus, Az demonstrated much better performance in grip strength test. At $0.1 \mathrm{mg} / \mathrm{kg}$ (the intermediate dose used) the Az effect was slightly more pronounced as compared to other nondepolarizing muscle relaxant pancuronium, the decrease being by $37 \%$ for Az and by $24.1 \%$ for pancuronium [20]. However, taking into consideration the 4.4-fold molecular mass difference, Az is much more active than pancuronium; $0.1 \mathrm{mg} / \mathrm{kg}$ corresponds 39 and $175 \mathrm{nmoles} / \mathrm{kg}$, respectively. In grip strength test the relaxant activity of botulinum neurotoxins was assessed in rats [20]. In this test, the botulinum neurotoxin was more active and its effect was much more persistent. At $0.24 \mathrm{U}$ of neurotoxin injected intramuscularly, the normal strength was not observed for more than 14 days [21]. This long muscle function disturbance might not be beneficial at some practical applications.

To study pharmacokinetics, the radioiodinated Az analogue was prepared. The only amino acid residue, which may be iodinated in the peptide, is histidine. Oxidative conditions used for iodination may result in oxidation of two tryptophan residues present in Az molecule. Therefore, to obtain the isotope-labeled derivative, a three-step procedure was chosen, including the introduction of formyl protective groups in the tryptophan residues, iodination of the protected Az using the iodide/chloramine T mixture and deprotection of the obtained derivative under alkaline conditions. The radioactive analogue possessing high radioactivity was used for the pharmacokinetics study. No lethality was observed at intravenous injection of $\left[{ }^{125} \mathrm{I}\right]-\mathrm{Az}$ at doses of 0.25 and $0.5 \mathrm{mg} / \mathrm{kg}$. While the dose of $0.5 \mathrm{mg} / \mathrm{kg}$ is very close to $\mathrm{LD}_{50}$ of $\mathrm{Az}(0.51 \mathrm{mg} / \mathrm{kg})$, it induced no death in injected mice. This fact may be explained by the lower toxicity of iodinated Az. Earlier we have shown that histidine residue is essential for Az activity [1]; its replacement by alanine resulted in strong decrease in capacity to bind to Torpedo nicotinic acetylcholine receptor. Thus, introduction of iodine in histidine residue may result in the decrease of $\left[{ }^{125} \mathrm{I}\right]$-Az toxicity.

Pharmacokinetics and pharmacodynamics are the empirical mathematical models that describe the time course of drug effect after administration [22]. Pharmacokinetics describes the disposition of 
drug in the organism, while pharmacodynamics relates the drug effects to their concentration in the plasma and at the site of action. They can be used to predict the drug action at different doses and by this way to optimize the safe and effective use of the drug. Information from pharmacokinetic studies can be used in the design and analysis of data from other toxicity studies. Several pharmacokinetics parameters for $\mathrm{Az}$ were determined including $\mathrm{AUC}(0 \rightarrow \mathrm{t}), \mathrm{C}_{\max }$ and $\mathrm{T}_{1 / 2}$. It was found that a higher Az concentration was achieved in the blood after its intravenous injection. We were not able to find in the available literature pharmacokinetics parameters obtained for any peripherally acting muscle relaxant in mice. However, there are several studies published for humans [23-26]. It should be noted that the results obtained on different species with different administered doses and different analysis methods cannot be compared adequately. Nondepolarizing peripherally acting muscle relaxant can be classified as long-acting, intermediate- and short-acting blockers [26]. By its pharmacokinetics parameters, $\mathrm{Az}$ is more similar to intermediate-acting relaxants. Its excretion half-life was estimated as 15-40 min depending on administration way, while for intermediate-acting relaxants in human it varied from $17 \mathrm{~min}$ (atracurium [27]) to $71 \mathrm{~min}$ (rocuronium [28]). For $\mathrm{Az}, \mathrm{C}_{\max }$ was $745 \mathrm{ng} / \mathrm{mL}$ at intravenous injection $(0.5 \mathrm{mg} / \mathrm{kg})$; this value was about $1 \mu \mathrm{g} / \mathrm{mL}$ for vecuronium [29] and $27 \mu \mathrm{g} / \mathrm{kg}$ for rocuronium [23]. It should be noted that for $\mathrm{Az}$ we observed fairly good correlation between the time of elimination (half-life $15-40 \mathrm{~min}$ ) and duration of muscle relaxant effect (25-55 $\mathrm{min}$ ).

Acute toxicity of Az was determined using different administration ways: intraperitoneal (ip), intramuscular (im) and intravenous (iv) injections. The highest toxicity was observed at iv injection $\left(\mathrm{LD}_{50} 0.51 \mathrm{mg} / \mathrm{kg}\right.$ ). The $\mathrm{LD}_{50}$ of rocuronium at iv injection to rats is about $0.3 \mathrm{mg} / \mathrm{kg}$ [30], for (+)-tubocurarine in mice- $0.11 \mathrm{mg} / \mathrm{kg}$ [31] and for vecuronium in mice $-50 \mu \mathrm{g} / \mathrm{kg}$ [32]. In our experiment, intramuscular injection of rocuronium at dose of $0.13 \mathrm{mg} / \mathrm{kg}$ resulted in the death of the animal, while $\mathrm{Az}$ at $0.7 \mathrm{mg} / \mathrm{kg}$ was not lethal. These data indicate that the Az possesses lower acute toxicity than common peripherally acting muscle relaxants. It should be noted that the surviving animals have fully recovered in a fairly short period of time. This is a standard feature of curare-like drugs and can be considered in favor of their application in practice.

The subchronic toxicity of Az was studied at its intramuscular administration in two doses of 0.1 and $0.5 \mathrm{mg} / \mathrm{kg}$ for 14 days. Among a number of different parameters investigated, several were found to be influenced by Az administration. Thus, in males receiving Az the differences from control males receiving the carrier were observed in the following parameters: the relative heart mass was increased by $0.076 \%$, the triglyceride level was decreased by $0.28 \mathrm{mmol} / \mathrm{L}$ and the platelet count was increased by $81 \mathrm{~g} / \mathrm{L}$. In the group of females treated with the drug at a dose of $0.1 \mathrm{mg} / \mathrm{kg}$, the differences from the control animals in some biochemical parameters were also found-the cholesterol level was lowered by $0.73 \mathrm{mmol} / \mathrm{L}$ and calcium concentration by $0.11 \mathrm{mmol} / \mathrm{L}$. However, these changes did not exceed the physiological norm and fall within the range of normal physiological values for male and female rats [14]. It would be incorrect to speak in this case about the toxic effects of Az, since the fluctuations of the parameters are within the range of the physiological norm. For the same reason, we cannot say that there are differences in the effects of $\mathrm{Az}$ on males and females. No other signs of toxicity were observed during chronic intramuscular administration of $\mathrm{Az}$ to female and male rats within a two-week withdrawal period. Therefore, we concluded that peptide had no significant chronic toxicity in rats at doses tested.

Like some other chemical substances, Az may induce undesirable immune reaction or allergy. Immunotoxicity is defined as adverse effects on the functioning of the immune system that result from exposure to chemical substances. The adverse effects on the immune system include reduction in antibody production, reduction in cytokine secretion, hypersensitivity and some other effects [33]. Altered immune function may lead to the increased incidence or severity of infectious diseases or cancer, since the immune system's ability to respond adequately to invading agents is suppressed. Identifying immunotoxicants is difficult because chemicals can cause a wide variety of complicated effects on immune function. That is why several methods were used in this work to estimate the immunotoxicity of azemiopsin. The precise testing of immunotoxicity and allergenicity is required 
to estimate the potential hazard of the putative drug. Immunotoxicity assays are important tests for new drugs being developed for application in the humans. Considering the complexity of the immune response, in vivo studies are more relevant. In this work, three different in vivo assays were used to assess Az immunotoxicity (Section 2.8). None of them revealed immunotoxic capacity of Az. No signs of allergenicity was seen in any of the in vivo tests described above; therefore, we decided first to try a single dose of $0.15 \mathrm{mg} / \mathrm{kg}$, which is close to the anticipated therapeutic one. Allergenicity of Az was checked as its ability to induce a delayed-type hypersensitivity reaction. This test did not reveal any allergenicity signs as well, then for ethical reasons we considered additional studies inappropriate. It should be noted that neuromuscular blocking agents contribute to $50-70 \%$ of allergic reactions during anesthesia [34]. Suxamethonium appeared to be more frequently involved, while, pancuronium and cis-atracurium are associated with the lowest incidence of anaphylaxis [34]. An increased frequency of allergic reactions to rocuronium was recently noted [35]. As no allergic reaction to Az was observed in our study it may have advantages over other relaxants in this respect.

Mutagenicity, that is the induction of permanent transmissible changes in the amount or structure of the genetic material of cells or organisms, is very important parameter of drug candidate. Highly mutagenic compounds can hardly be considered for drug development, therefore mutagenicity studies are a necessary phase in preclinical evaluations. In vitro Az mutagenicity studies using mammalian $\mathrm{CHO}-\mathrm{k} 1$ cells showed no mutagenic capacity. While studies of rocuronium using cultured human peripheral blood lymphocytes indicated that it was capable of causing genotoxicity via clastogenic effects at concentrations at which a significant cytotoxic effect does not occur [36]. Thus, Az is safer as compared to rocuronium.

The main application of NMRs is their use in surgery to relax the muscles during operative interventions. They are administered during anesthesia and allow to reduce the dose of anesthetics thus decreasing their adverse effects. There are some general requirements to NMR and ideally, it should have a rapid onset and short duration of action, no cardiovascular side effects, no accumulation in the body, no active metabolites, organ-dependent drug metabolism and elimination as well as an available and adequate antagonist $[37,38]$. Az satisfies most these requirements: it is fast acting agent with relatively short duration of action, does not accumulates in the body and has no active metabolites. All this allows considering Az for the possible application as NMR.

As it was described in introduction, other area for muscle relaxant application is the treatment of dystonia. Nowadays the main drug for dystonia treatment is extremely toxic botulinum toxin. In addition to high toxicity, there are several other side effects associated with its application. Az at non-lethal doses showed good muscle relaxing activity (Figure 3). It is deprived of some shortcomings (e.g., long action period) inherent in the botulinum toxin and may be regarded as a candidate for dystonia treatment.

The above considerations allow to conclude that $\mathrm{Az}$ has good drug-like properties for the application as local muscle relaxant, however further studies should be conducted to confirm it safety and applicability including investigation on humans.

\section{Conclusions}

In summary, we investigated the preclinical profile of $\mathrm{Az}$ in regard to in vitro and in vivo efficacy, acute and chronic toxicity, pharmacokinetics, allergenic capacity, immunotoxicity and mutagenic potency. Our in vitro studies confirmed the high affinity and specificity of Az for muscle type nAChR. The peptide effectively inhibited muscle $\mathrm{nAChR}$ but was less potent at $\alpha 7 \mathrm{nAChR}$ and had a low affinity to $\alpha 4 \beta 2$ and $\alpha 3$-containing $\mathrm{nAChR}$, as well as to GABAA or 5HT3 receptors. Its muscle relaxant effect was demonstrated at intramuscular injection to mice at doses of 30-300 $\mu \mathrm{g} / \mathrm{kg}$, the relaxant activity being higher than that of commonly used peripheral muscle relaxants. The highest acute toxicity was observed at intravenous injection of $\mathrm{Az}$, at intramuscular or intraperitoneal administration it was less toxic. No toxicity signs were observed at doses inducing muscle relaxant effects. Toxicology studies in mice indicated that Az was well tolerated during chronic dosing and showed no immunotoxicity, 
allergenic or mutagenic activity, which differ if from most currently used muscle relaxants. Overall, the results demonstrate that azemiopsin has good drug-like properties for application as a local muscle relaxant and in its parameters is not inferior to the relaxants currently used. It should be noted that Az possessed narrow therapeutic window, which is a typical characteristic and a weak point for all muscle relaxants with a similar mechanism of action. Modifications are required that will not affect (or preferably increase) the effectiveness of the drug but reduce its toxicity and extend its narrow therapeutic window.

\section{Materials and Methods}

\subsection{Materials}

A polystyrene-poly(ethylene glycol) 2000 block-copolymer resin, modified with Knorr linker Tentagel S RAM was from Rapp Polymere GmbH (Tübingen, Germany). Fmoc-protected amino acids, 4-methyl piperidine were from Mosinter (Ningbo, China). 1-[Bis(dimethylamino)methylene]- 1H-1,2,3-triazolo[4,5-b]pyridinium 3-oxid hexafluorophosphate (HATU), 1-Hydroxy-7-azabenzotriazole (HOAt) and DL-Dithiothreitol (DTT) were from DEMO Medical (Shanghai, China). N,N-diisopropylethylamine (DIPEA) was from Iris Biotech $\mathrm{GmbH}$ (Marktredwitz, Germany), trifluoroacetic acid from Solvay S.A. (Bruxelles, Belgium), normal saline (sterile $0.9 \% \mathrm{NaCl}$ solution), complete Freund's adjuvant and trinitrobenzenesulfonic acid (TNBS) from Sigma-Aldrich Chemie Gmbh (Munich, Germany), bovine serum albumin (BSA) from Amresko, Rocuronium Bromide from Fresenius Kabi (Bad Homburg, Germany). All other reagents and solvents of the highest purity available were purchased from local manufacturers and used without additional purification.

\subsection{Animals}

Specific pathogen-free (SPF) ICR mice (6-8 weeks old, weight 29-34 g) and SD rats (9-11 weeks old, weight of males 254-310 g, weight of females 188-220 g) of both sexes were obtained from the Animal House of the Branch of the Shemyakin-Ovchinnikov Institute of Bioorganic Chemistry, Russian Academy of Sciences and used for studies in vivo. Animals were housed in groups of 5-6 mice or 2 rats at $20-25^{\circ} \mathrm{C}, 30-70 \%$ relative humidity and under a 12-h light-dark cycle (lights on at 08:00). Standard chow for rodents and filtered tap water were provided ad libitum. All studies involving animals were approved by the Institutional Animal Care and Use Committee (IACUC) of the Branch of the Shemyakin-Ovchinnikov Institute of Bioorganic Chemistry, Russian Academy of Sciences, the experimental protocol codes are No. 528/16, 531/16, 534/16, 560/16, 576/17, 577/17. The dates of approval are 31 March 2016, 20 April 2016, 20 May 2016, 15 September 2016, 10 February 2017, 10 February 2017, respectively. All solutions for in vivo studies were prepared fresh before the administration: the necessary amount of freeze-dried $\mathrm{Az}$ was dissolved in normal saline $(0.9 \%$ sterile $\mathrm{NaCl}$ solution).

\subsection{Az Synthesis}

\subsubsection{Solid Phase Az Synthesis}

Az synthesis was performed on automatic peptide synthesizer based on Gilson automated liquid handler system according to Gilson application note 228. The peptide was synthesized utilizing a solid phase methodology with Fmoc/t-Bu protection scheme. A polystyrene-poly(ethylene glycol) 2000 block-copolymer resin Tentagel S (extent of loading 0.3 meq/g) was modified with Knorr linker followed by peptide chain assembly. A 4-fold excess of protected amino acids was used; condensation reagent was HATU/HOAt in amount equimolar to that of protected amino acids and activation reagent-2.4 equivalents of DIPEA. Coupling time for 7 C-terminal amino acid residues (up to Pro15) was $1 \mathrm{~h}$ and for subsequent residues the coupling time was increased to $2 \mathrm{~h}$. For His9 and Pro15 
residues a repetitive coupling was required to achieve their complete acylation. After chain assembly, peptidyl-polymer was subjected to a total deprotection/cleavage by the treatment with $12 \mathrm{~mL}$ of reagent L [39] per $1 \mathrm{~g}$ of dry resin for $2 \mathrm{~h}$. After that, the resin was filtered, washed with trifluoroacetic acid and combined filtrate was evaporated under vacuum to ca. $30 \%$ of initial volume. The residue was diluted tenfold with dry diethyl ether; the precipitated crude peptide was filtered out, washed with ether and dried under vacuum. The crude peptide was dissolved in starting buffer and $1 \mathrm{~g}$ was applied on a ECOPlus column $(35 \times 250 \mathrm{~mm})$ packed with $60 \mathrm{~mL}$ of SPS-Bio CM $(12 \mu \mathrm{m}$, Purolite Corporation, Bala Cynwyd, PA, USA) resin. The column was eluted with 8 column volumes of linear concentration gradient of ammonium bicarbonate from $50 \mathrm{mM}$ to $1 \mathrm{M}$ (pH 8.9) in 10\% isopropyl alcohol. Fractions containing peptide were collected and isopropyl alcohol was evaporated under vacuum, the remaining solution was freeze-dried. Freeze-dried peptide was dissolved in water to a final concentration of $50 \mathrm{mg} / \mathrm{mL}$, titrated with acetic acid to a $\mathrm{pH} 3.5$ and applied on a Thermo Scientific Hypersil GOLD $\mathrm{aQ}(12 \mu \mathrm{m}, 250 \times 50 \mathrm{~mm})$ column. Elution was carried out with a linear gradient of acetonitrile in water from 10 to $35 \%$ in $30 \mathrm{~min}$ in the presence of $1 \%$ acetic acid at a flow rate of $150 \mathrm{~mL} / \mathrm{min}$. Main fraction was collected and freeze-dried; the obtained azemiopsin acetate had a purity greater than $97 \%$ as confirmed by UPLC-MS analysis. The total yield of pure peptide was about $20 \%$, based on resin loading.

\subsubsection{Formylation of $\mathrm{Az}$}

For this modification, the peptide was dissolved in formic acid at a concentration of $50 \mathrm{mg} / \mathrm{mL}$, to the resulting solution hydrogen chloride in formic acid was added to a final concentration of $200 \mathrm{mM}$ $\mathrm{HCl}$. The mixture was stirred for $12 \mathrm{~h}$, then formic acid was evaporated on a rotary evaporator, the residue was dissolved in water and freeze-dried. The formylation was complete, as evidenced by HPLC-MS analysis.

\subsubsection{Iodination of Formylated Az}

The iodination was carried out in general according to the published procedure [13]. In brief, $500 \mu \mathrm{L}$ of diformyl azemiopsin solution in water $(2.2 \mathrm{mM})$ were mixed with $100 \mu \mathrm{L}$ of $1 \mathrm{M}$ Tris- $\mathrm{HCl}$ buffer (pH 6.8), $30 \mu \mathrm{L}$ of $\mathrm{Na}^{127} \mathrm{I}$ solution $(100 \mathrm{mM})$ and $15 \mu \mathrm{L}$ of $\mathrm{Na}^{125}$ I solution with specific radioactivity of $2000 \mathrm{Ci} / \mathrm{mmole}$. Then $27 \mu \mathrm{L}$ of a $100 \mathrm{mM}$ chloramine $\mathrm{T}$ solution was added to the mixture, the solution was mixed vigorously and incubated for $30 \mathrm{~min}$ at room temperature. The radioiodinated product was isolated by HPLC on Jupiter C18 column $(10 \mu \mathrm{m}, 10 \times 250 \mathrm{~mm}$, Phenomenex) in a linear gradient of acetonitrile in water from 10 to $25 \%$ in $15 \mathrm{~min}$ in the presence of $0.1 \%$ trifluoroacetic acid at a flow rate of $1 \mathrm{~mL} / \mathrm{min}$. The fraction containing diiodinated diformyl azemiopsin was concentrated on Savant SpeedVac Centrifuge Concentrator SVC100D and the solution obtained was used for deprotection.

\subsubsection{Deprotection of Radioiodinated Az}

To remove formyl protecting groups, the radioiodinated Az derivative was treated with $100 \mathrm{mM}$ sodium hydroxide solution for $12 \mathrm{~h}$. HPLC-MS analysis showed almost complete $(>90 \%)$ removal of the formyl groups. After deblocking, the reaction mixture was neutralized with dilute hydrochloric acid, giving a solution of diiodoazemiopsin in an isotonic solution of sodium chloride. The concentration of $\mathrm{Az}$ in the resulting solution was determined spectrophotometrically from the absorbance at $280 \mathrm{~nm}$ and the radioactivity was measured using Wizard 1470 Automatic Gamma Counter (Perkin Elmer, Waltham, MA, USA). The specific radioactivity of the derivative was $0.15 \mathrm{Ci} / \mathrm{mmole}$. 


\subsection{Toxicity Studies}

\subsubsection{Acute Toxicity}

\section{Az Acute Toxicity}

Az acute toxicity was estimated for its intravenous (iv) and intramuscular (im) administration to male ICR mice in a stepwise procedure.

For the iv route of administration, 20 mice were randomly divided in 5 groups of 4 animals each. The animals of each group received a single dose of $\mathrm{Az}(0.3,0.4,0.5,0.6$, or $0.7 \mathrm{mg} / \mathrm{kg}$, respectively) injected into the lateral tail vein at a volume of $1 \mathrm{~mL} / \mathrm{kg}$. For the im route of administration, first two experimental groups of 3 animals each were formed. Az at doses of 0.75 and $1.0 \mathrm{mg} / \mathrm{kg}$, respectively, was injected into the quadriceps muscle of the thigh (quadriceps femoris muscle) of two mouse hind limbs at a volume of $0.5 \mathrm{~mL} / \mathrm{kg}$ to each muscle. Then, five experimental groups of 5 animals each were formed. Az was injected into the quadriceps muscle of the thigh (quadriceps femoris muscle) of the two hind limbs of male ICR mice at doses of $0.8,0.775,0.75,0.725 \mathrm{and} 0.7 \mathrm{mg} / \mathrm{kg}$. The injection volume to each limb was $1 \mathrm{~mL} / \mathrm{kg}$. Further, neurotoxic manifestations were recorded in animals at 5, 10, 20, 30, 60 and $90 \mathrm{~min}$ and $24 \mathrm{~h}$ after administration using the functional observation battery, the number of death was counted as well.

After iv and im injections of Az, the mice were observed for $24 \mathrm{~h}$ and signs of toxicity or lethality were recorded. For the iv and im route of administration, the median lethal dose $\left(\mathrm{LD}_{50}\right)$ was calculated using a probit analysis [40]. For the im route of administration, the maximum tolerated dose was determined.

\section{Rocuronium Acute Toxicity}

Rocuronium was administered intramuscularly at doses of $0.13 \mathrm{mg} / \mathrm{kg}(n=1), 0.1 \mathrm{mg} / \mathrm{kg}(n=4)$ and $0.08 \mathrm{mg} / \mathrm{kg}(n=4)$ in the triceps of the forelimbs of male ICR mice $(8-9$ weeks old $)$. Control animals were injected with saline $(n=4)$. The volume of administration was $0.5 \mathrm{~mL} / \mathrm{kg}$ in each limb.

\subsubsection{Subchronic Toxicity}

A repeated dose 14-day intramuscular toxicity study was conducted on 36 SD male and 36 SD female adult rats. They were divided into 3 groups. The first control group was given normal saline, the second and the third experimental groups received $\mathrm{Az}$ at doses of $0.1 \mathrm{mg} / \mathrm{kg}$ and $0.5 \mathrm{mg} / \mathrm{kg}$, respectively, daily for 14 days. The substances were injected into the quadriceps muscle of the thigh. Every day the animals were examined and any clinical signs of intoxication, body weight and food intake were recorded. The one half of the animals were euthanized on the 15th day of the study, the second half-after a 2-week cancellation period on the 29th day of the study. All animals were autopsied and their organs were inspected for any pathological signs, weighed and histologically examined. The ratio of organ-to-body weight was calculated for several organs: brain, heart, liver, spleen, thymus, kidneys, lungs, testicles and ovaries. The histological analysis was carried out for a number of organs: kidney, adrenal glands, testis, ovary, spleen, thymus, brain, heart, lung, liver, lymph node (mesenteric and mandibular), stomach, skin and muscle from the site of the administration.

A biochemical analysis of blood serum parameters was performed. A level of aspartate aminotransferase, alanine aminotransferase, glutamate dehydrogenase, alkaline phosphatase, gamma-glutamyl transferase, urea nitrogen, creatinine, total bilirubin, total protein, albumin, globulin, phosphorus, calcium, total cholesterol, triglycerides, albumin/globulin ratio was estimated. The analysis was performed using Randox GB reagent kits for each tested parameter and the automatic biochemical analyzer Sapphire-400 (Tokyo Boeki Ltd., Toyko, Japan).

A hematological analysis of animal blood included the evaluation of red and white blood cell number, a hemoglobin level, hematocrit, red cell distribution width, mean corpuscular volume (MCV), mean corpuscular hemoglobin $(\mathrm{MCH})$, mean corpuscular hemoglobin concentration (MCHC), platelets 
number, a mean platelet volume, a mean platelet component and a cell number of neutrophils, eosinophils, basophils, lymphocytes, monocytes, large unstained cells, reticulocytes. The analysis was performed using a hematological analyzer Mythic 18 Vet (C2 DIAGNOSTICS S.A., Montpellier, France).

\subsection{Pharmacokinetics}

The pharmacokinetic study was performed using 163 male ICR mice. Four experimental groups with 40 animals in each were formed. Three intact mice were used as control animals. The animals of the first two experimental groups were intravenously injected with 0.25 and $0.50 \mathrm{mg} / \mathrm{kg}\left[{ }^{125} \mathrm{I}\right]-\mathrm{Az}$, respectively. The animals of the other two experimental groups were intramuscularly injected with 0.25 and $0.50 \mathrm{mg} / \mathrm{kg}\left[{ }^{125} \mathrm{I}\right]-\mathrm{Az}$, respectively. To estimate Az elimination rate, animal blood samples were taken from the orbital sinus 5, 15, 30, 60 min and 1, 2, 4 and $24 \mathrm{~h}$ after $\left[{ }^{125} \mathrm{I}\right]-\mathrm{Az}$ administration. The obtained blood samples were weighed. For each indicated time point, $\left[{ }^{125} \mathrm{I}\right]-\mathrm{Az}$ concentration was calculated as a mean value in blood samples of five animals. The radioactivity (cpm) in the blood samples was counted using a Wallac 1470 WIZARD ${ }^{\circledR}$ Gamma Counter (Perkin Elmer, Waltham, MA, USA). The specific radioactivity of $\left[{ }^{125} \mathrm{I}\right]-\mathrm{Az}$ was $6.26 \times 10^{7} \mathrm{cpm} / \mathrm{mg}$. Radioactivity data (cpm) were re-calculated to the concentration of $\left[{ }^{125} \mathrm{I}\right]-\mathrm{Az}$ in the obtained blood samples. The specific pharmacokinetic parameters (AUC $\left.(0 \rightarrow \mathrm{t}), \mathrm{C}_{\max }, \mathrm{T}_{1 / 2}\right)$ of $\left[{ }^{125} \mathrm{I}\right]$-Az were estimated.

\subsection{Mutagenicity}

The ability of Az to induce mutations in the hypoxanthine guanine phosphoribosyltransferase (hprt) gene of Chinese hamster ovary CHO-k1 cells was tested. The cells were purchased from the Russian collection of cell cultures (Institute of Cytology, Russian Academy of Sciences, Saint Petersburg, Russia). CHO-k1 cells were cultured in the growth medium DMEM/F12 with high glucose, glutamine and without $\mathrm{Na}_{2} \mathrm{CO}_{3}$, HEPES (Sigma-Aldrich Chemie Gmbh, Munich, Germany) supplemented with 10\% FBS (BioSera, Nuaille, France), $0.1 \mathrm{M} \mathrm{HEPES,} 80 \mathrm{mg} / \mathrm{mL}$ gentamicin and $10 \mathrm{mg} / \mathrm{mL}$ fluconazole at $37{ }^{\circ} \mathrm{C}, 5 \% \mathrm{CO}_{2}$ in a $\mathrm{CO}_{2}$ incubator. Before Az treatment $\mathrm{CHO}-\mathrm{k} 1$ cells were subcultured and incubated in HAT medium (5 mM hypoxanthine, $20 \mathrm{mM}$ aminopterin and $0.8 \mathrm{mM}$ thymidine (Sigma-Aldrich Chemie Gmbh, Munich, Germany)) for three days, then the medium was changed and they were cultured for one day in HT medium (5 mM hypoxanthine and $0.8 \mathrm{mM}$ thymidine (Sigma-Aldrich Chemie Gmbh, Munich, Germany)). After that, the cells were subcultured at a density of 40,000 cells per $\mathrm{cm}^{2}$ in 10 -cm Petri dishes. Next day they were treated for $4 \mathrm{~h}$ with different Az concentrations ranging from 2.8 to $2000 \mu \mathrm{g} / \mathrm{mL}$ in the presence or absence of a metabolic activation system (S9 mixture [15]). As positive controls, two high-mutagenic agents were used: ethylnitrosurea $(6.25$ and $12.5 \mu \mathrm{g} / \mathrm{mL})$ and methylcholanthrene ( 2.5 and $5 \mu \mathrm{g} / \mathrm{mL}$ ) in the absence and in the presence of the metabolic activation system, respectively.

After the treatment, the CHO-k1 cells were partly subcultured at a density of 150-500 cells per $55 \mathrm{~cm}^{2}$ to determine the cytotoxicity of the different Az doses and control substances. The substance cytotoxicity was determined by a relative survival (RS) capacity of the cells, calculated as a ratio between the cloning efficiency (CE) of the cells plated immediately after the treatment and the normal cellular CE of non-treated cells (negative controls) after 7 days of culturing.

$$
\begin{gathered}
R S=\frac{\text { CE of the treated cells }}{\text { CE of non }- \text { treated cells }} \times 100 \\
C E=\frac{\text { Number of colonies }}{\text { Number of cells plated }}
\end{gathered}
$$

The rest of the treated $\mathrm{CHO}-\mathrm{k} 1$ cells were maintained in the growth medium for 8 days to allow near-optimal phenotypic expression of any induced in hprt gene mutations. Then, to determine the frequency of the induced mutations, the cells were subcultured and maintained in the growth medium in the presence $(2,000,000$ cells $)$ or in the absence (500 cells) of a selective agent $(2.2 \mu \mathrm{g} / \mathrm{mL}$ 6-thioguanine) for 7 days. After that, the number of cell colonies in both media was counted and the frequency of mutations was calculated with the formula: 


$$
\text { Mutation frequency }=\frac{C E \text { of mutant cells in a selective medium }}{C E \text { of cells in a non- selective medium }}
$$

\subsection{Immunotoxicity}

Three separate immunotoxicity tests were performed: (1) evaluation of cellular immunity in a delayed-type hypersensitivity test, (2) evaluation of animal immune response to a standard antigen, (3) evaluation of the phagocytic activity of peritoneal macrophages.

For carrying out these experiments 90 male ICR mice were used, they were divided equally into three groups (30 animals per group) for each study and in these groups they were subdivided into subgroups of 10 mice each and treated as follows: mice of the first subgroup were injected with normal saline im, the second subgroup animals were treated with $\mathrm{Az}(0.15 \mathrm{mg} / \mathrm{kg} \mathrm{im})$ and the animals of the third subgroup were treated with $\mathrm{Az}(0.50 \mathrm{mg} / \mathrm{kg} \mathrm{im})$. The drugs were injected into the quadriceps muscle of the thigh (musculus quadriceps femoris) daily for seven days $(1 \mathrm{~mL} / \mathrm{kg}$ ).

\subsubsection{Evaluation of Cellular Immunity in a Delayed-Type Hypersensitivity Test}

On the last 7th day of the Az administration, the mice of the first group (30 animals) were immunized with a solution of trinitrobenzenesulfonic acid (TNBS) $(200 \mu \mathrm{L}, 10 \mathrm{mM})$ subcutaneously at the base of a tail. After 6 days the animals were secondarily immunized with TNBS (50 $\mu \mathrm{L}, 10 \mathrm{mM})$ injected in the pad of the left hind paw, the same volume of normal saline was injected into the right hind paw. $24 \mathrm{~h}$ after the second immunization, the animals were euthanized $\left(\mathrm{CO}_{2}\right.$ inhalation $)$ and the weights of their experimental and control paws were determined. The reaction index was calculated using the indicated formula:

$$
R_{i}=\frac{W_{\exp }-W_{\text {cont }}}{W_{\exp }} \times 100 \%
$$

$R_{i}$-reaction index, $W_{\text {exp }}$-weight of the experimental paw, $W_{\text {cont }}$-weight of the control paw.

\subsubsection{Evaluation of Animal Immune Response to a Standard Antigen}

On the last 7th day of the Az administration, the mice of the second group (30 animals) were immunized intraperitoneally with a 1:1 mixture of $200 \mu \mathrm{L}$ of bovine serum albumin (BSA, $0.5 \mathrm{mg} / \mathrm{mL}$ ) with a complete Freund's adjuvant. 10 days after the 1st immunization, the mice received the second $200 \mu \mathrm{L}$ ip injection of the antigen (BSA, $0.5 \mathrm{mg} / \mathrm{mL}$ ) in an incomplete Freund's adjuvant (1:1 ratio). After 7 days the venous mouse blood was collected from the inferior vena cava, then the blood serum was isolated and the titers of IgG antibodies to BSA were determined using a standard enzyme immunoassay.

\subsubsection{Phagocytic Activity of Peritoneal Macrophages}

On the next day after the seven-day course of the $\mathrm{Az}$ administration, the mice of the third group (30 animals) were injected intraperitoneally with $2 \mathrm{~mL}$ of ink particles suspension. After $10 \mathrm{~min}$ the mice were euthanized $\left(\mathrm{CO}_{2}\right.$ inhalation) with a subsequent isolation of the peritoneal exudate from their abdominal cavity. In the exudate $(1 \mu \mathrm{L})$ the total number of peritoneal macrophages and the number of the ink particle-containing (phagocytic) cells among them were counted using a Gorjaev's chamber.

\subsection{Allergenicity}

Allergenicity of Az was studied in a delayed-type hypersensitivity test on male (20 animals) and female (20 animals) adult ICR mice. The mice were divided into four groups (two control and two experimental groups) of 10 animals (males or females) per group. Mice of the experimental groups were injected subcutaneously at the base of a tail with Az solution $(0.15 \mathrm{mg} / \mathrm{kg})$ emulsified in Freund's complete adjuvant in a ratio of 1:1 $(2 \mathrm{~mL} / \mathrm{kg})$. Similarly, the mice in the control groups 
were administered with a suspension of normal saline in Freund's complete adjuvant. Five days later all animals received an injection of $\mathrm{Az}(0.15 \mathrm{mg} / \mathrm{kg}, 1.33 \mathrm{~mL} / \mathrm{kg})$ in the pad of the left hind paw. To estimate the intensity of the studied allergic reaction, 6, 12 and $24 \mathrm{~h}$ after the second Az injection the thickness of the left and right hind mouse paws was measured with a digital caliper.

\subsection{Efficacy and Specificity Studies}

\subsubsection{Neuroblastoma Cell Culturing and Transient Transfection}

Human neuroblastoma cells SH-SY5Y were cultured in DMEM/F12 medium (ThermoFisher Scientific, Waltham, MA, USA) supplemented with 10\% fetal bovine serum (FBS) (PAA Laboratories $\mathrm{GmbH}$, Pasching, Austria), $2.5 \mu \mathrm{g} / \mathrm{mL}$ amphotericin B and $50 \mu \mathrm{g} / \mathrm{mL}$ gentamicin in a $\mathrm{CO}_{2}$ incubator at $37^{\circ} \mathrm{C}$ and $5 \% \mathrm{CO}_{2}$ atmosphere. Cells were sub-cultured and plated at a density of 5000-10,000 cells per well in a 96-well black plate (Corning Inc., Corning, NY, USA). They were grown in a $\mathrm{CO}_{2}$ incubator for $48-72 \mathrm{~h}$ before testing the functional activity of natively expressed $\mathrm{nAChRs}$ by calcium imaging.

Mouse neuroblastoma Neuro2a cells were purchased from the Russian collection of cell cultures (Institute of Cytology, Russian Academy of Sciences, Saint Petersburg, Russia). Cells were cultured in DMEM (Paneco, Moscow, Russia) supplemented with 10\% FBS. They were sub-cultured the day before transfection and were plated at a density of 10,000 cells per well in a 96-well black plate. On the next day Neuro2a cells were transiently transfected with plasmids coding mouse muscle $\alpha 1 \beta 1 \delta \varepsilon \mathrm{nAChR}$ (pRBG4-vector) and a fluorescent calcium sensor Case12 (pCase12-cyto vector, Evrogen, Moscow, Russia) in a molar ratio of 2:1 following a lipofectamine transfection protocol (ThermoFisher Scientific, Waltham, MA, USA). Human $\alpha 7 \mathrm{nAChR}(\alpha 7 \mathrm{nAChR}-\mathrm{pCEP} 4)$ was expressed accordingly with a co-expression of the human chaperone Ric-3 (Ric3-pCMV6-XL5, OriGene, Rockville, MD, USA) in a molar ratio $4: 1$. The transfected cells were grown at $37^{\circ} \mathrm{C}$ in a $\mathrm{CO}_{2}$ incubator for $48-72 \mathrm{~h}$, before performing the calcium imaging assay.

\subsubsection{Calcium Imaging}

Calcium imaging procedure was performed as published earlier [11]. Briefly, after removing the growth medium, the transfected Neuro2a cells and cultivated SH-SY5Y cells were washed with a buffer containing $140 \mathrm{mM} \mathrm{NaCl}, 2 \mathrm{mM} \mathrm{CaCl}_{2}, 2.8 \mathrm{mM} \mathrm{KCl}, 4 \mathrm{mM} \mathrm{MgCl}$, $20 \mathrm{mM} \mathrm{HEPES,} 10 \mathrm{mM}$ glucose; $\mathrm{pH}$ 7.4. Neuro2a cells expressing muscle $\mathrm{nAChR}$ and the protein calcium sensor Case12 were proceeded directly, while SH-SY5Y cells expressing human $\alpha 3$-containing nAChRs natively were loaded with a fluorescent dye Fluo-4, AM (1.824 $\mu \mathrm{M}$, ThermoFisher Scientific, Waltham, MA, USA) and a water-soluble probenecid (1.25 mM, ThermoFisher Scientific, Waltham, MA, USA) for 30 min at $37^{\circ} \mathrm{C}$ and then were kept for $30 \mathrm{~min}$ at room temperature according to the manufacturer's protocol.

To detect the human $\alpha 7 \mathrm{nAChR}$-mediated calcium response, transfected Neuro2a cells were incubated with its positive allosteric modulator PNU120596 (10 $\mu \mathrm{M}$, Tocris Bioscience, Bristol, UK) for $20 \mathrm{~min}$ at room temperature before acetylcholine (Sigma-Aldrich Chemie Gmbh, Munich, Germany) addition. To assess mouse muscle or human $\alpha 3$-containing nAChRs this step was skipped. Transfected Neuro2a cells expressing muscle or $\alpha 7 \mathrm{nAChRs}$ and SH-SY5Y cells expressing $\alpha 3$-containing nAChRs natively were preincubated with $\mathrm{Az}$ for 15 minutes at room temperature before agonist addition.

The plates were transferred to the multimodal microplate reader Hidex Sence (Hidex, Turku, Finland) where the cells were excited by light of $485 \mathrm{~nm}$ wavelength and emitted fluorescence was detected at $535 \pm 10 \mathrm{~nm}$. Fluorescence was recorded every $2 \mathrm{~s}$ for three minutes following agonist addition. Responses were measured as peak intensity minus basal fluorescence level and were expressed as a percentage of the maximal response obtained to agonist. Data files were analyzed using Hidex Sence software (Hidex, Turku, Finland) and OriginPro 7.5 software (OriginLab, Northampton, MA, USA, for statistical analysis). 


\subsubsection{Electrophysiological Experiments}

Ovary tissue from adult female Xenopus laevis was cut into small pieces and these pieces were digested with collagenase A ( $4 \mathrm{mg} \mathrm{mL}^{-1}$, Worthington Biochemical Corp., Lakewood, NJ, USA) in Barth's solution without calcium $(88.0 \mathrm{mM} \mathrm{NaCl}, 1.1 \mathrm{mM} \mathrm{KCl}, 2.4 \mathrm{mM} \mathrm{NaHCO} 3,0.8 \mathrm{mM} \mathrm{MgSO}$, 15.0 mM HEPES/NaOH, pH 7.6) for $1.5 \pm 2 \mathrm{~h}$ at $20^{\circ} \mathrm{C}$. The oocytes were stored in Barth's solution with calcium $\left(88.0 \mathrm{mM} \mathrm{NaCl}, 1.1 \mathrm{mM} \mathrm{KCl}, 2.4 \mathrm{mM} \mathrm{NaHCO}_{3}, 0.3 \mathrm{mM} \mathrm{Ca}\left(\mathrm{NO}_{3}\right)_{2}, 0.4 \mathrm{mM} \mathrm{CaCl}, 0.8 \mathrm{mM}\right.$ $\mathrm{MgSO}_{4}, 15.0 \mathrm{mM}$ HEPES/NaOH, pH 7.6) supplemented with $63.0 \mu \mathrm{g} / \mathrm{mL}$ penicillin-G sodium salt, $40.0 \mu \mathrm{g} / \mathrm{mL}$ streptomycin sulfate and $40.0 \mu \mathrm{g} / \mathrm{mL}$ gentamicin. Stage V $\pm \mathrm{VI}$ oocytes were selected and injected with $3 \mathrm{ng}$ plasmids coding the rat $\alpha 4$ and $\beta 2 \mathrm{nAChR}$ subunits (pcDNA3.1 vector) in a molar ratio of 1:1 using an Auto-Nanoliter Injector NanoJect-2 (Drummond Scientific Company, Broomall, PA, USA) in a total injection volume of $23 \mathrm{~nL}$. After injection, oocytes were incubated at $18{ }^{\circ} \mathrm{C}$ in Barth's solution with calcium for 48-120 h. Electrophysiological recordings were made using a Turbo TEC-03X amplifier (npi electronic GmbH, Tamm, Germany) and WinWCP recording software (University of Strathclyde, Glasgow, UK). Oocytes were placed in a small recording chamber with a working volume of $50 \mu \mathrm{L}$ and $100 \mu \mathrm{L}$ of ligands ( $50 \mu \mathrm{M} \mathrm{Az}, 20 \mu \mathrm{M}$ nicotine) solution in Barth's buffer were applied to an oocyte. Az was pre-applied to an oocyte for $5 \mathrm{~min}$ before its co-application with agonist nicotine. To allow receptor recovery from desensitization, the oocytes were superfused for 5-10 min with buffer $(1 \mathrm{~mL} / \mathrm{min})$ between ligand applications. Electrophysiological recordings were performed at a holding potential of $-60 \mathrm{mV}$.

\subsubsection{In Vivo Muscle Relaxant Effect}

In Vivo Muscle Relaxant Effect of Az

40 male ICR mice were divided equally into four groups: one control and three experimental groups. Animals of the control and experimental groups were treated with normal saline and with $\mathrm{Az}$ at doses of $0.03,0.1$ and $0.3 \mathrm{mg} / \mathrm{kg}$, respectively. In addition 6 mice were treated with $\mathrm{Az}$ at dose of $0.01 \mathrm{mg} / \mathrm{kg}$. The corresponding solutions were injected into the triceps muscles of the mouse forelimbs at a volume of $0.5 \mathrm{~mL} / \mathrm{kg}$ per each limb. For all animals their basic forelimb grip strength was recorded before the substance administration with a 1027 grip strength meter (Columbus Instruments, Columbus, OH, USA). Further, their grip strength was measured 5, 10, 15, 20, 30, 60, 90 min after the $\mathrm{Az}$ (or normal saline) im administration.

\section{In Vivo Muscle Relaxant Effect of Rocuronium}

Rocuronium was administered intramuscularly as described for the measurement of acute toxicity (Section 5.4.1). Muscle strength was assessed prior to administration of the substance and then 1, 2, 3, 4,5 min after administration.

\subsection{Statistical Analysis}

The statistical analysis of the obtained results was performed using Statistica 7.1 (TIBCO Software Inc., Palo Alto, CA, USA) and OriginPro 9.1 (Microcal, Northampton, MA, USA) software. The data of Az efficacy in vivo were analyzed using one-way repeated measures ANOVA test. To statistically evaluate the efficacy and specificity of Az in vitro, two-tailed Mann-Whitney U test was used. The data of Az subchronic toxicity, immunotoxicity and allergenicity were analyzed using Kruskall-Wallis ANOVA on ranks test. Results are expressed as mean of data \pm SEM unless otherwise stated. In all tests, $p<0.05$ was taken as significant.

Supplementary Materials: The following are available online at www.mdpi.com/2072-6651/10/1/34/s1, Figure S1: Muscle relaxant effect of $\mathrm{Az}$ at dose of $0.01 \mathrm{mg} / \mathrm{kg}$.

Acknowledgments: This study was supported by the Russian Science Foundation (project No. 16-14-00215). 
Author Contributions: I.V.S., M.N.Z. and A.V.L. conceived and designed the experiments; I.V.S., M.N.Z., A.V.L., I.A.I., A.I.G., I.N.K., E.A.R., M.A.S., E.A.T., V.A.R., G.A.S. and N.S.E. performed the experiments; I.V.S., M.N.Z., A.V.L., I.S.M., V.I.T. and Y.N.U. analyzed the data; I.A.I. and N.S.E contributed materials; I.V.S., A.V.L., I.A.I, A.I.G., V.I.T. and Y.N.U. wrote the paper.

Conflicts of Interest: The authors declare no conflict of interest. The founding sponsors had no role in the design of the study; in the collection, analyses, or interpretation of data; in the writing of the manuscript and in the decision to publish the results.

\section{References}

1. Utkin, Y.N.; Weise, C.; Kasheverov, I.E.; Andreeva, T.V.; Kryukova, E.V.; Zhmak, M.N.; Starkov, V.G.; Hoang, N.A.; Bertrand, D.; Ramerstorfer, J.; et al. Azemiopsin from Azemiops feae viper venom, a novel polypeptide ligand of nicotinic acetylcholine receptor. J. Biol. Chem. 2012, 287, 27079-27086. [CrossRef] [PubMed]

2. Unwin, N. Nicotinic acetylcholine receptor and the structural basis of neuromuscular transmission: Insights from Torpedo postsynaptic membranes. Q. Rev. Biophys. 2013, 46, 283-322. [CrossRef] [PubMed]

3. Jonsson, F.M.; Dabrowski, M.; Eriksson, L.I. Pharmacological characteristics of the inhibition of nondepolarizing neuromuscular blocking agents at human adult muscle nicotinic acetylcholine receptor. Anesthesiology 2009, 110, 1244-1252. [CrossRef]

4. Bowman, W.C. Neuromuscular block. Br. J. Pharmacol. 2006, 147, S277-S286. [CrossRef] [PubMed]

5. Habre, W.; Adamicza, A.; Lele, E.; Novák, T.; Sly, P.D.; Petak, F. The involvement of histaminic and muscarinic receptors in the bronchoconstriction induced by myorelaxant administration in sensitized rabbits. Anesth. Analg. 2008, 107, 1899-1906. [CrossRef] [PubMed]

6. Bornia, E.C.; Bando, E.; Machinski, M., Jr.; Pereira, M.W.; Alves-Do-Prado, W. Presynaptic M1, M2, and A1 receptors play roles in tetanic fade induced by pancuronium or cisatracurium. J. Anesth. 2009, 23, 513-519. [CrossRef] [PubMed]

7. Albanese, A.; Bhatia, K.; Bressman, S.B.; Delong, M.R.; Fahn, S.; Fung, V.S.; Hallett, M.; Jankovic, J.; Jinnah, H.A.; Klein, C.; et al. Phenomenology and classification of dystonia: A consensus update. Mov. Disord. 2013, 28, 863-873. [CrossRef] [PubMed]

8. Kudryavtsev, D.; Shelukhina, I.; Vulfius, C.; Makarieva, T.; Stonik, V.; Zhmak, M.; Ivanov, I.; Kasheverov, I.; Utkin, Y.; Tsetlin, V. Natural compounds interacting with nicotinic acetylcholine receptors: From low-molecular weight ones to peptides and proteins. Toxins 2015, 7, 1683-1701. [CrossRef] [PubMed]

9. Utkin, Y.N.; Zhmak, M.N.; Andreeva, T.V.; Weise, C.; Kryukova, E.V.; Tsetlin, V.I.; Kasheverov, I.E.; Starkov, V.G. Peptide Azemiopsin Selectively Interacting with Nicotinic Cholinoreceptors of the Muscle Type and Suitable for Use as Muscle Relaxant in Medicine and Cosmetology. Russian Patent R.U. 2,473,559, 26 October 2011. (In Russian)

10. Kasheverov, I.; Zhmak, M.; Chivilyov, E.; Saez-Brionez, P.; Utkin, Y.; Hucho, F.; Tsetlin, V. Benzophenone-type photoactivatable derivatives of $\alpha$-neurotoxins and $\alpha$-conotoxins in studies on Torpedo nicotinic acetylcholine receptor. J. Recept. Signal Transduct. Res. 1999, 19, 559-571. [CrossRef] [PubMed]

11. Shelukhina, I.; Spirova, E.; Kudryavtsev, D.; Ojomoko, L.; Werner, M.; Methfessel, C.; Hollmann, M.; Tsetlin, V. Calcium imaging with genetically encoded sensor Case12: Facile analysis of $\alpha 7 / \alpha 9 \mathrm{nAChR}$ mutants. PLoS ONE 2017, 12, e0181936. [CrossRef] [PubMed]

12. Tsomides, T.J.; Eisen, H.N. Stoichiometric labeling of peptides by iodination on tyrosyl or histidyl residues. Anal. Biochem. 1993, 210, 129-135. [CrossRef] [PubMed]

13. Kasheverov, I.E.; Zhmak, M.N.; Khruschov, A.Y.; Tsetlin, V.I. Design of new $\alpha$-conotoxins: From computer modeling to synthesis of potent cholinergic compounds. Mar. Drugs 2011, 9, 1698-1714. [CrossRef] [PubMed]

14. Hall, R.L. Clinical Pathology of Laboratory Animals. In Animal Models in Toxicology, 2nd ed.; Gad, S.C., Ed.; CRC Press Taylor \& Francis Group: Boca Raton, FL, USA, 2007; pp. 787-830.

15. Johnson, G.E. Mammalian Cell HPRT Gene Mutation Assay: Test Methods. In Genetic Toxicology. Methods in Molecular Biology (Methods and Protocols); Parry, J., Parry, E., Eds.; Springer: New York, NY, USA, 2012; Volume 817, ISBN 978-1-61779-420-9.

16. Matsuoka, M.; Hayashi, M.; Ishidate, M., Jr. Chromosomal aberration tests on 29 chemicals combined with S9 mix in vitro. Mutat. Res. 1979, 66, 277-290. [CrossRef] 
17. Legal Portal of Eurasian Economic Union. Available online: https://docs.eaeunion.org/docs/ru-ru/ 01411927/cncd_21112016_81 (accessed on 5 January 2018). (In Russian)

18. Jonsson, M.; Gurley, D.; Dabrowski, M.; Larsson, O.; Johnson, E.C.; Eriksson, L.I. Distinct pharmacologic properties of neuromuscular blocking agents on human neuronal nicotinic acetylcholine receptors: A possible explanation for the train-of-four fade. Anesthesiology 2006, 105, 521-533. [CrossRef] [PubMed]

19. Montilla-García, Á.; Tejada, M.Á.; Perazzoli, G.; Entrena, J.M.; Portillo-Salido, E.; Fernández-Segura, E.; Cañizares, F.J.; Cobos, E.J. Grip strength in mice with joint inflammation: A rheumatology function test sensitive to pain and analgesia. Neuropharmacology 2017, 125, 231-242. [CrossRef] [PubMed]

20. Nevins, M.E.; Nash, S.A.; Beardsley, P.M. Quantitative grip strength assessment as a means of evaluating muscle relaxation in mice. Psychopharmacology 1993, 110, 92-96. [CrossRef] [PubMed]

21. Torii, Y.; Kiyota, N.; Sugimoto, N.; Mori, Y.; Goto, Y.; Harakawa, T.; Nakahira, S.; Kaji, R.; Kozaki, S.; Ginnaga, A. Comparison of effects of botulinum toxin subtype A1 and A2 using twitch tension assay and rat grip strength test. Toxicon 2011, 57, 93-99. [CrossRef] [PubMed]

22. Wright, P.M. Population based pharmacokinetic analysis: Why do we need it; what is it; and what has it told us about anaesthetics? Br. J. Anaesth. 1998, 80, 488-501. [CrossRef] [PubMed]

23. Yuan, G.; Zhang, R.; Wang, B.; Wei, C.; Liu, X.; Zhao, W.; Guo, R. Determination of Rocuronium in Human Plasma by High Performance Liquid Chromatography-Tandem Mass Spectrometry and its Pharmacokinetics in Patients. J. Bioequiv. Availab. 2012, 4, 7. [CrossRef]

24. Van Miert, M.M.; Eastwood, N.B.; Boyd, A.H.; Parker, C.J.; Hunter, J.M. The pharmacokinetics and pharmacodynamics of rocuronium in patients with hepatic cirrhosis. Br. J. Clin. Pharmacol. 1997, 44, 139-144. [CrossRef] [PubMed]

25. Dragne, A.; Varin, F.; Plaud, B.; Donati, F. Rocuronium pharmacokinetic-pharmacodynamic relationship under stable propofol or isoflurane anesthesia. Can. J. Anaesth. 2002, 49, 353-360. [CrossRef] [PubMed]

26. Naguib, M.; Lien, C.A. Pharmacology of muscle relaxants and their antagonists. In Miller's Anesthesia, 6th ed.; Churchill Livingstone: London, UK, 2005; Volume 3, pp. 493-515.

27. Vandenbrom, R.H.; Wierda, J.M.; Agoston, S. Pharmacokinetics and neuromuscular blocking effects of atracurium besylate and two of its metabolites in patients with normal and impaired renal function. Clin. Pharmacokinet. 1990, 19, 230-240. [CrossRef] [PubMed]

28. Szenohradszky, J.; Fisher, D.M.; Segredo, V.; Caldwell, J.E.; Bragg, P.; Sharma, M.L.; Gruenke, L.D.; Miller, R.D. Pharmacokinetics of rocuronium bromide (ORG 9426) in patients with normal renal function or patients undergoing cadaver renal transplantation. Anesthesiology 1992, 77, 899-904. [CrossRef] [PubMed]

29. Lebrault, C.; Berger, J.L.; D’Hollander, A.A.; Gomeni, R.; Henzel, D.; Duvaldestin, P. Pharmacokinetics and pharmacodynamics of vecuronium (ORG NC 45) in patients with cirrhosis. Anesthesiology 1985, 62, 601-605. [CrossRef] [PubMed]

30. SAGENT Pharmaceuticals. Available online: http://www.sagentpharma.com/wp-content/uploads/2015/ 05/Rocuronium_SDS.pdf (accessed on 5 January 2018).

31. Ginsburg, S.; Kitz, R.J.; Savarese, J.J. Neuromuscular blocking activity of a new series of quaternary N-substituted choline esters. Br. J. Pharmacol. 1971, 43, 107-126. [CrossRef] [PubMed]

32. SAGENT Pharmaceuticals. Available online: http://www.sagentpharma.com/wp-content/uploads/2017/ 04/Vecuronium_SDS.pdf (accessed on 5 January 2018).

33. Descotes, J. Immunotoxicology: Role in the safety assesment of drugs. Drug Saf. 2005, 28, 127-136. [CrossRef] [PubMed]

34. Peroni, D.G.; Sansotta, N.; Bernardini, R.; Crisafulli, G.; Franceschini, F.; Caffarelli, C.; Boner, A.L. Muscle relaxants allergy. Int. J. Immunopathol. Pharmacol. 2011, 24, S35-S46. [CrossRef] [PubMed]

35. Reddy, J.I.; Cooke, P.J.; van Schalkwyk, J.M.; Hannam, J.A.; Fitzharris, P.; Mitchell, S.J. Anaphylaxis is more common with rocuronium and succinylcholine than with atracurium. Anesthesiology 2015, 122, 39-45. [CrossRef] [PubMed]

36. Zan, U.; Topaktas, M.; Istifli, E.S. In vitro genotoxicity of rocuronium bromide in human peripheral lymphocytes. Cytotechnology 2011, 63, 239-245. [CrossRef] [PubMed]

37. Moore, E.W.; Hunter, J.M. The new neuromuscular blocking agents: Do they offer any advantages? Br. J. Anaesth. 2001, 87, 912-925. [CrossRef] [PubMed]

38. Kim, Y.B.; Sung, T.-Y.; Yang, H.S. Factors that affect the onset of action of non-depolarizing neuromuscular blocking agents. Korean J. Anesthesiol. 2017, 70, 500-510. [CrossRef] [PubMed] 
39. Bonner, A.G.; Udell, L.M.; Creasey, W.A.; Duly, S.R.; Laursen, R.A. Solid-phase precipitation and extraction, a new separation process applied to the isolation of synthetic peptides. J. Pept. Res. 2001, 57, 48-58. [CrossRef] [PubMed]

40. Finney, D.J. Probit Analysis, 3rd ed.; Cambridge University Press: Cambridge, MA, USA, 1971. 